\title{
Gas Stream Cleanup
}

\author{
Technology Status Report
}

\author{
S. J. Bossart \\ D. C. Cicero \\ C. M. Zeh \\ R. C. Bedick
}

\begin{abstract}
U.S. Department of Energy
Office of Fossil Energy

Morgantown Energy Technology Center

P.O. Box 880

Morgantown, West Virginia 26507-0880
\end{abstract}

August 1990 


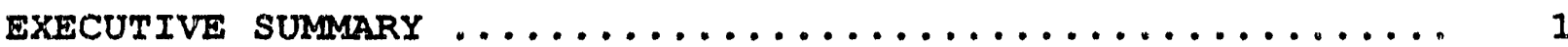

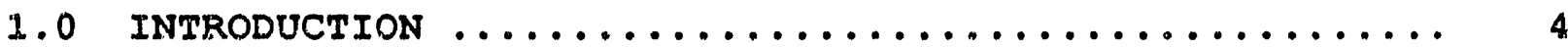

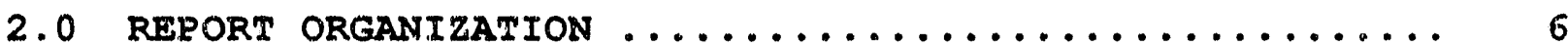

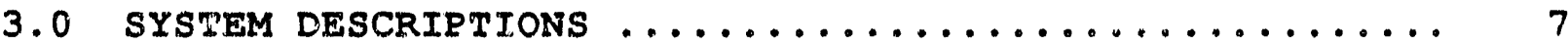

3.1 Rressurized Fluidized-Bed Combustion

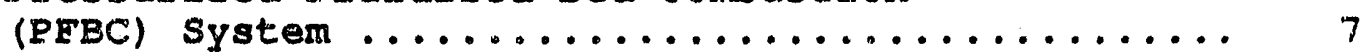

3.2 Direct Coal-Fueled Turbine (DCFr) system ........ 7

3.3 Integrated Gasification Combined-Cycle

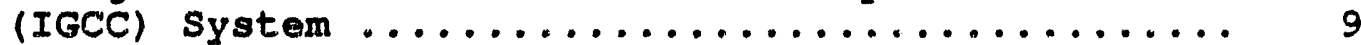

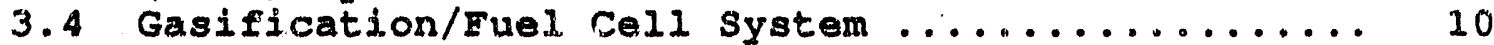

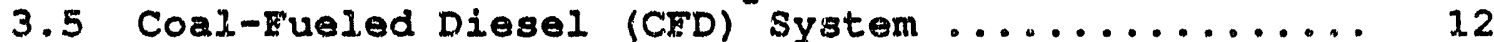

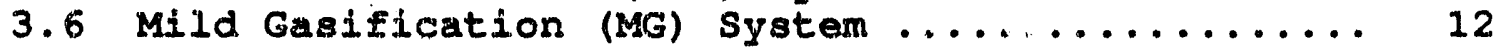

4.0 GAS STREAM CHEANUP STATUS AND ASSESSMENT ...........

4.1 Gas strean Cleanup for Pressurized Fluidized-

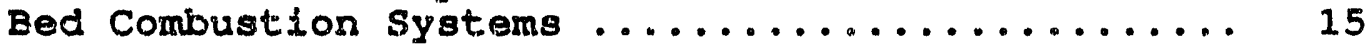

4.2 Gas Stream Cleanup for Direct Coal-Fueled

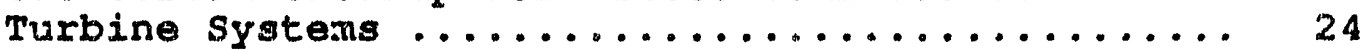

4.3 Gas Stream Cleanup for Integrated Gasification Combined-Cycle systems ........... 29

4.4 Gas stream Cleanup for Gasification/

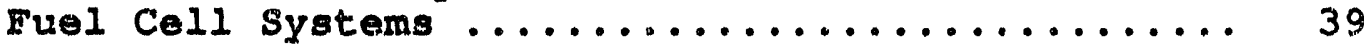

4.5 Gas stream Cleanup for Coal-Eueled

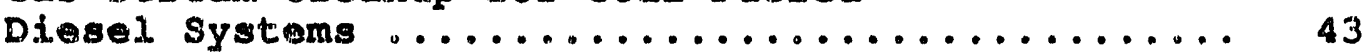

4.6 Gas Stream Cleanup for Mild Gasification

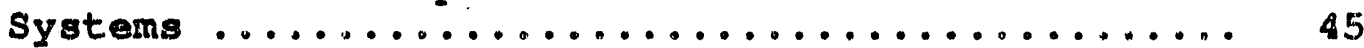

5.0 SUPPORTING GAS STREAM CLEANUP RESEARCH ........... 47

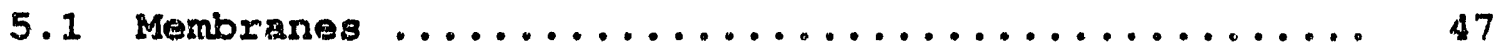

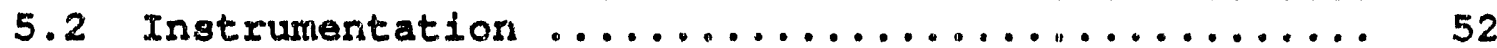

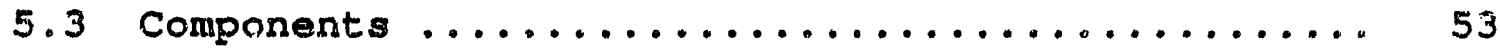

6.0 ACRONYMS AND ABBREVIATIONS ..................... 54

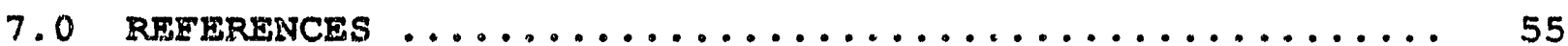

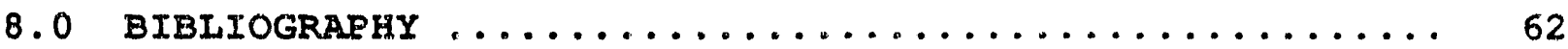


1 Pressurized Fluidized-Bed Combustion Systems ......

Direct Coal-Fueled Turbine system .............. Integrated Gasification Combined-Cycle system ..... Gasifier/Fuel Cell systems ..................

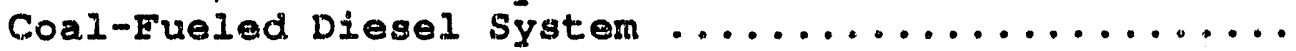

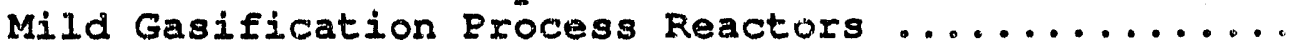
Ceramic Cross-Flow rilter .................. Performance of Ceramic Cross-Flow Filter and Screenless Granular Bed Filter at NYU PFBC ........ Screenless Granular Bed Filter system ........... Westinghouse ILEC Concept ................. Tube Type Electrostatic Agglomerator ............ GE Gasifier and Moving-Bed, Hot Gas

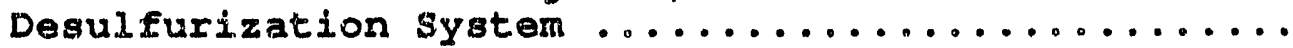
ALCOA Separations Technology Division's

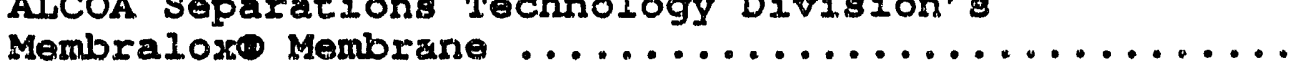

\section{IIST OF TABRES}

Table

Page

1 Contaminant Control Goals and Operating Conditions in PFBC systems ..................

2 Expected Operating Conditions for Hot Gas Cleanup Tests at Ohio Power Company Tidd

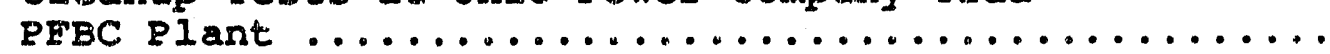

3 Conditions and Cleanup Goals of the Direct

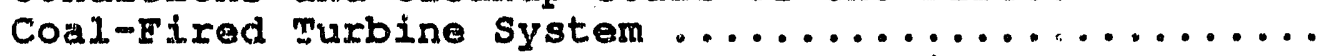

4 Contarinant Control Goals and operating

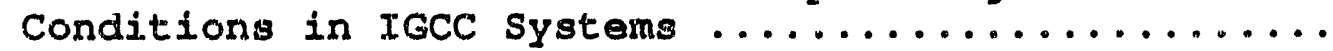

5 Molten Carbonate ruel Cell Contaminants and Tolerance Limits ........................ 
This report describes the current status and recent accomplishments of gas stream cleanup (GSCU) projects sponsored by the Morgantown Energy Technology Center (METC) of the U.S. Department of Energy (DOE). The primary goal of the Gas stream Cleanup Program is to develop contaminant control strategies that meet environmental regulations and protect equipment in advanced coal conversion systems. Contaminant control systems are being developed for integration into seven advanced coal conversion

processes:

- Pressurized fluidized-bed combustion (PFBC)

- Direct coal-fueled turbine (DCET)

- Integrated gasification combined-cycle (IGCC)

- Gasification/molten carbonate fuel cell (MCEC)

- Gasification/solid oxide fuel cell (SOFC)

- Coal-fueled diesel (CFD)

- Mild gasification (MG)

These advanced coal conversion systems present a significant challenge for developinent of contaminant control systems because they generate multi-contaminant gas streams at high-pressures (i.e., greater than 0.51 megapascals [MPa] [5 atmospheres (atm)]) and high-temperatures (i.0., greater than $\left.538^{\circ} \mathrm{C}\left[1,000^{\circ} \mathrm{F}\right]\right)$. The contaminants of major concern in these systems are sulfur compounds, nitrogen compounds, alkali compounds, halogenated compounds, particles, tars, and trace contaminants. Each of the seven advanced coal conversion systems incorporates distinct contaminant control strategies because each has different contaminant tolerance limits and operating conditions. Great strides have been made in the development of contaminant control systems for the advanced coal conversion processes as evidenced by the fol.lowing recent accomplishments.

Prec. Iests at the Grimethorpe and New York University (NYU) PFBC facilities demonstrated the ability of the ceramic cross-flow filter, ceramic candle filter, and screenless granular bed filter (GBE) to meet environmental regulations for particle emissions and particle tolerance limits for protection of gas turbines. Acoustic agglomeration and the nested fiber filter are also being developed for RFBC applications, although they are less mature technologies than those tested at NYU and Grimethorpe. Beginning in 1992, a large-scale, hot gas test program at the ohio Power Company Tidd-PFBC facility provides an opportunity to evaluate commercial-size modules of advanced particle control technologies. In addition, activated bauxite and emathlite have been effective in removing alkali compoinds under PFBC conditions. In PFBC systerns, in-bed desulfurization with calcium-based sorbents is sufficient for meeting environmental regulations, while nitrogen oxides $\left(\mathrm{NO}_{x}\right)$ emissions are minimal due to the low combustion temperature. 
DCrry. Four contractors are evaluating and developing contaminant control strategies for DCET systems: Westinghouse; General Motors, Allison Gas Turbine Division; Solar Turbines; and Research cottrell. The contaminant controi requirements and operating conditions are currently unclear, because DCFT are in the initial stage of development. Ceramic candle filter systems, an electrostatic agglomeratox, and mechanical separators are being tested for their ability to control particles in DCET systems. Suitable sorbents have been identified for control of sulfur compounds (e.g., limestone) and alkali compounds (e.g., emathlite and hectorite). Staged combustion is being used to mitigate the generation of $\mathrm{NO}_{\mathrm{x}}$ in the DCFT systems.

IGCC. Major IGCC projects included tests at the KelloggRust-Westinghouse (KRW) fluidized-bed gasification facility and the Texaco entrained-bed gasification facility. In-bed desulfuriztion tests at $\mathrm{KRW}$ demonstrated the ability of calcium-based sorbents to remove greater than 90 percent of the sulfur, while in-bed desulfurization tests at Texaco demonstrated up to 60 percent sulfur removal. At KRW, a packed-bed of zinc ferrite remornd sulfur down to levels less than 20 parts per million by volume (ppmv) when operating with and without in-bed desulfurization. The zine ferrite sorbent was easily regenerated with air and steam for multi-cycle operation. Slipstream testing at Texaco showed that four regenerable, inixed-metal oxide sorbents were able to remove greater than 99.9 percent of the sulfur. Testing of a 33-element candle filter system at KRW demonstrated the ability of the ceramic candle filter to meet New Source Performance standards (NSPS) for particle emissions and particle tolerance limits for gas turbines. Testing of a ceramic crossflow filter Bystem at Texaco showed that the cross-flow filter could remove particles to less than 10 parts per million by weight (ppmw), but the pressure drop was higher than expected due to the fine char/ash produced by the gasifier.

Several large-scale IGCC projects axe nearing their testing phases. GE Environmental Services has recently initiated tests on a moving-bed, hot gas desulfurization system at the GE fixedbed gasification facility. Calderon will be testing a gasification/hot gas cleanup process targeted toward electric power production with co-production of methanol and elemental sulfux. Southern Company Services (SCS) was recently awarded a 5-year cooperative agreement to evaluate advanced particle control technulogies under both gasification and combustion conditions.

MCrC, sorf. The gasification/fuel systems have more stringent contaminant tolerance limits than the IGCC systems. Energy Research Corporation has established preliminary contaminant tolexance limits for gasification/MCFC systems based on single contaminant expnsure teats with a MCFC. They are currently 
investigating the possible synergistic effects of multiple contaminants on MCEC performance. SRI International and the Institute of Gas Technology (IGT) have developed hydrogen chloride removal (HCl) sorbents for MCFC applications. Nahcolite was identified as the best HCl removal sorbent because of its low cost and high capacity. Westinghouse is beginning to investigate the effects of coal contaminants on SOFC performance.

CrD. Coal-fueled diesel systems are being developed for the small power generation market and the transportation sector Cyclone separators, a granular bed filter, and a metal candle filter are being evaluated as particle control technologies in diesel systems. Three methods being evaluated for $\mathrm{NO}_{x}$ control are reburning, reduction with carbon-containing particulate matter, and selective non-catalytic reduction. The primary method of sulfur control is injection of calcium-based sorbents at various locations in the diesel system. A granular bed filter with copper oxide-coated alumina pellets removed greater than 95 percent of the particles and greater than 90 percent of the sulfux in the GE coal-fired locomotive system.

MG. The requirements for contaminant control in mild gasification processes are currently unclear, because mild gasification systems are in the initial phase of development. It is expected that removal of particulates, sulfur compounds, nitrogen compounds, chlorides, alkali compounds, and trace metals will be required to enhance the value of multiple products (i.e., gas, liquid, and char) from mild gasification processes.

Supposting Research. The technology areas of membranes, instrumentation, and components are applicable to all advanced coal conversion systems. Aluminum Company of America (AlCOA) and SRI International are pursuing the development of passive membranes for gas separation. Worcester Rolytechnic Institute (WPI) is interested in developing catalytic membranes to decompose and remove ammonia $\left(\mathrm{NH}_{3}\right)$ and hydrogen sulfide $\left(\mathrm{H}_{2} \mathrm{~S}\right)$. Air Products and Chemicals (AP\&C) is using a facilitated transport membrane that uses carbonate salts to enhance gas separation. Instrumentation developments that have been implemented into the gas stream cleanup projects include the Fiber optic Alkali Monitor (FOAM) and smart structures. FOAM has bees used to measure gasphase alkali concentrations at several coal-burning facilities. The term "smart structures" refers to fiber optic sensing systems used to detect strain, temperature, and particle cake on ceramic barrier filters (e.g., candle and cross-flow filters). This information is useful in predicting component life and improving design. In the component development area, Oak Ridge National Laboratory (ORNL) is evaluating tubesheet design and material selection. Ceramic barrier filters are attached to tubesheets in advanced particle filter systems. 


\subsection{INMRODUCTION}

The Gas Stream Cleanup Program is one of several coal technology areas supported by the Morgantown Energy Technology Center of the U.S. Department of Energy. GSCU is a common feature of all advanced coal conversion systems. Thus, GSCU activities must be integrated with other mainline METC programs (i.e., Gasification, Combustion, Fuel Cells, and Heat Engines), which support development of advanced coal conversion systems. This technology status report provides an overview of the technical status and achievements of GSCU activities in all METC programs, and updates the last Gas Stream Cleanup Technology status Report, which was published in October 1988 (Williams and Bedick 1988). The projects emphasized in the report are projects that use coalderived gas for evaluation of GSCU concepts and projects with major technical achievements.

The objective of the GSCU Program at DOE/METC is to develop control technologies that manage coal-derived contaminants genexated in advanced coal-fueled combustion and gasification processes. The major focus of the GSCU Program is to develop contaminant control technologies that operate at pressures greater than $0.51 \mathrm{MPa}(5 \mathrm{~atm})$ and temperatures greater than $538^{\circ} \mathrm{C}$ $\left(1,000^{\circ} \mathrm{F}\right)$. These elevated pressures and temperatures are associated with seven emexging coal conversion systems: pressurized fluidized-bed combustion, direct coal-fueled turbine, integrated gasification combined-cycle, gasification/molten carbonate fuel cell, gasification/solid oxice fuel cell, coal-fueled diesel, and mild gasification. The advantages of controlling coal-derived contaminants at elevated temperatures and pressures include elimination of expensive heat recovery equipment; reduction of losses in energy conversion efficiency associated with fuel-gas quenching; and reduction in wast awater treatment requirements.

The contaminants of major cuncern in the GSCU Program are sulfur compounds, nitrogen compounds, alkali compounds, halogenated compounds, particles, tars, and trace contaminants. These contaminants must be controlled because they are regulated environmental pollutants, detrimental to the performance of system equipment, or both. Specifically:

- Sulfur control is required to meet environmental regulations for sulfur dioxide $\left(\mathrm{SO}_{2}\right)$ emissions, although sulfur removal to lower levels is needed to protect fuel cells.

- The formation and release of nitrogen oxides must be controlled in all systerns to meet environmental. regulations. 
Ammonia produced in coal gasifiers must be removed or converted to molecular nitrogen $\left(\mathrm{N}_{2}\right)$ to reduce subsequent formation of $\mathrm{NO}_{x}$ when combusted in the gas turbine.

- Alkali compounds, consisting primarily of sodium and potassium compounds such as sodium sulfate $\left(\mathrm{Na}_{2} \mathrm{SO}_{4}\right)$ and potassium sulfate $\left(\mathrm{K}_{2} \mathrm{SO}_{4}\right)$, can also react with the ceramic materials used in construction of advanced particle filters. Filtration performance and strength of the filters can be adversely affected by these reactions. Excessive alkali and halogenated compounds (e.g., HCl) can cause significant electrolyte loss in fuel cells through volatilization.

- Particles must be controlled to neet environmental regulations and to protect system equipment such as the gas turbine and fuel cell. Particles play an important role in erosion, corrosion, and deposition of all system equipment. Erosion is caused by the high-speed impaction of particles on the turbine blades. Particle deposition can impede gas flow and block cooling air. Particle deposition contributes to corrosion when alkali compounds adsoxbed on the particles react with the turbine blades.

- Tars, composed mostly of heavy aromatic hydrocarbons, can foul valves, piping, advanced particle filters, and heat exchange equipment. Tars can also deactivate sulfur sorbents and catalysts. The nitrogen and sulfur content of tars may require reduction to help meet environmental regulations for emissions of $\mathrm{NO}_{x}$ and $\mathrm{SO}_{2}$.

- Although present at low concentrations, trace contaminants, such as arsenic ( $A s$ ), cadmium (Cd), mercury (Hg), lead ( $\mathrm{Bb}$ ), selenium $(S e)$, and zinc $(\mathrm{z} n)$, can degrade the performance of: energy conversion systems and harm the environment. 


\subsection{REPORT ORGANIZATION}

Section 3.0, System Descriptions, describes the seven emerging coal conversion systems: pressurized fluidized-bed combustion, direct coal-fueled tuxbine, integrated gasification combined-cycle, gasification/molten carbonate fuel cell, gasification/solid oxide fuel cell, coal-fueled diesel, and mild gasification.

Section 4.0, Gas Stream Cleanup Status and Assessment, provides the current status of gas stream activities according to their applicability to a paxticular coal conversion system and offers an assessment of these activities. However, many of the research and development activities in gas strearn cleanup have applicability to more than one advanced coal conversion system because several of the advanced coal conversion systems share similarities in gas composition, temperature, and pressure. In general, the discussion of a specific gas stream cleanup activity can be found under the system in which its development has proceeded most rapidly.

Section 5.0, Supporting Gas Stream Cleanup Research, discusses gas stream activities relating to the development of gas separation membranes, instrumentaition, and components. These activities are applicable to all coal conversion systems. In general, measurement units for temperature, pressure, mass, and length are expressed in System International units, with American engineering units given in parentheses. 


\subsection{SXSTHM DHSCRIPTIONS}

\subsection{Pressurized Bluidized-Bed Combustion (BPBC) System}

A schematic of a first-generation, bubbling-bed PFBC system is shown in Figure 1. Properly sized coal and sulfur sorbent. (e.g., dolomite or limestone) are fluidized by air fed through a perforated plate at the bottom of the combustox. As the coal burns, the released sulfur compounds react with the sorbent to form a solid material that is removed with the coal ash at the bottom of the combustor. Heat is removed within the combustor by in-bed heat exchangers that produce stearn to drive a steam turbine. Combustion gases exit tra combustor and are expanded in a gas turbine to produce additional power. The steam cycle generates 65 to 75 percent of the electric powor, while the gas turbine generates 25 to 35 percent of the power. The firstgeneration PEBC system may attain 40 percent energy conversion. efficiency as compared to 30 percent efficiency for a typical, conventional, pulverized-coal boiler with a steam turbine.

A schematic of a second-generation PFBC is also shown in Figure 1. This concept attempts to use the full power-producing capabilities of modern steam and gas turbines by increasing the temperature of the gas entering the gas turbine by means of a topping combustor. Coal is fed to a partial gasifier (pyrolyzer) that produces char and low-Btu gas. The char is burned in a PFBC, and the exhaust gas is filtered to remove particles prior to ontry into the topping combustor. Low-Btu gas from the gasifier is also filtered to remove particles priox to entry into the topping combustor. Both the PEBC and the partial gasifier use in-bed desulfurization sorbents (e.g., dolomite or limestone) to control emissions of sulfur dioxide. In the topping combustor, any aix required to complete combustion is mixed with the lowBtu gas and PFBC exhaust gas. The topping combustor is designed to achieve gas turbine inlet temperatures of 1,093 to $1,316^{\circ} \mathrm{C}$ $\left(2,000\right.$ to $\left.2,400^{\circ} \mathrm{F}\right)$. Steam produced by in-bed heat exchangers in the EFBC drives a stean turbine. Performance goals for secondgeneration PFBC systems are efficiencies approaching 45 percent and cost of electricity (COE) reductions of at least 20 percent below conventional, pulverized-coal boilers with flue gas desulfurization.

\subsection{Direct Coal-Fueled Turbine (DCFT) syatem}

A schematic of a DCE'T system is shown in Figure 2. The feedstock for DCET systems is dry, pulverized coal or a coalwater slurry. The coal is burned directly in the combustor, and the exhaust gas is expanded in the turbine. Contaminants must be removed within the combustion chamber or from exhaust gases 


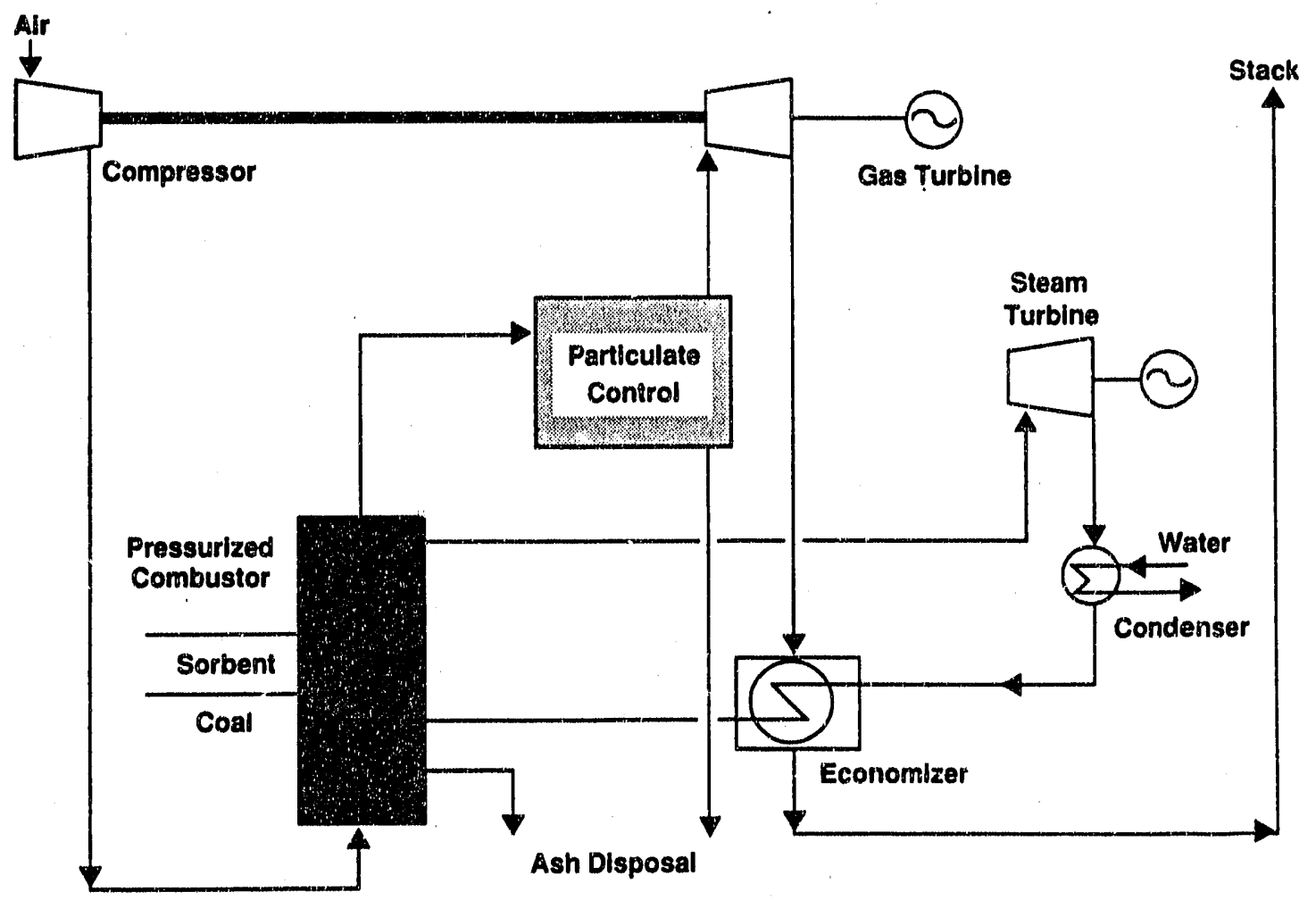

First Generation

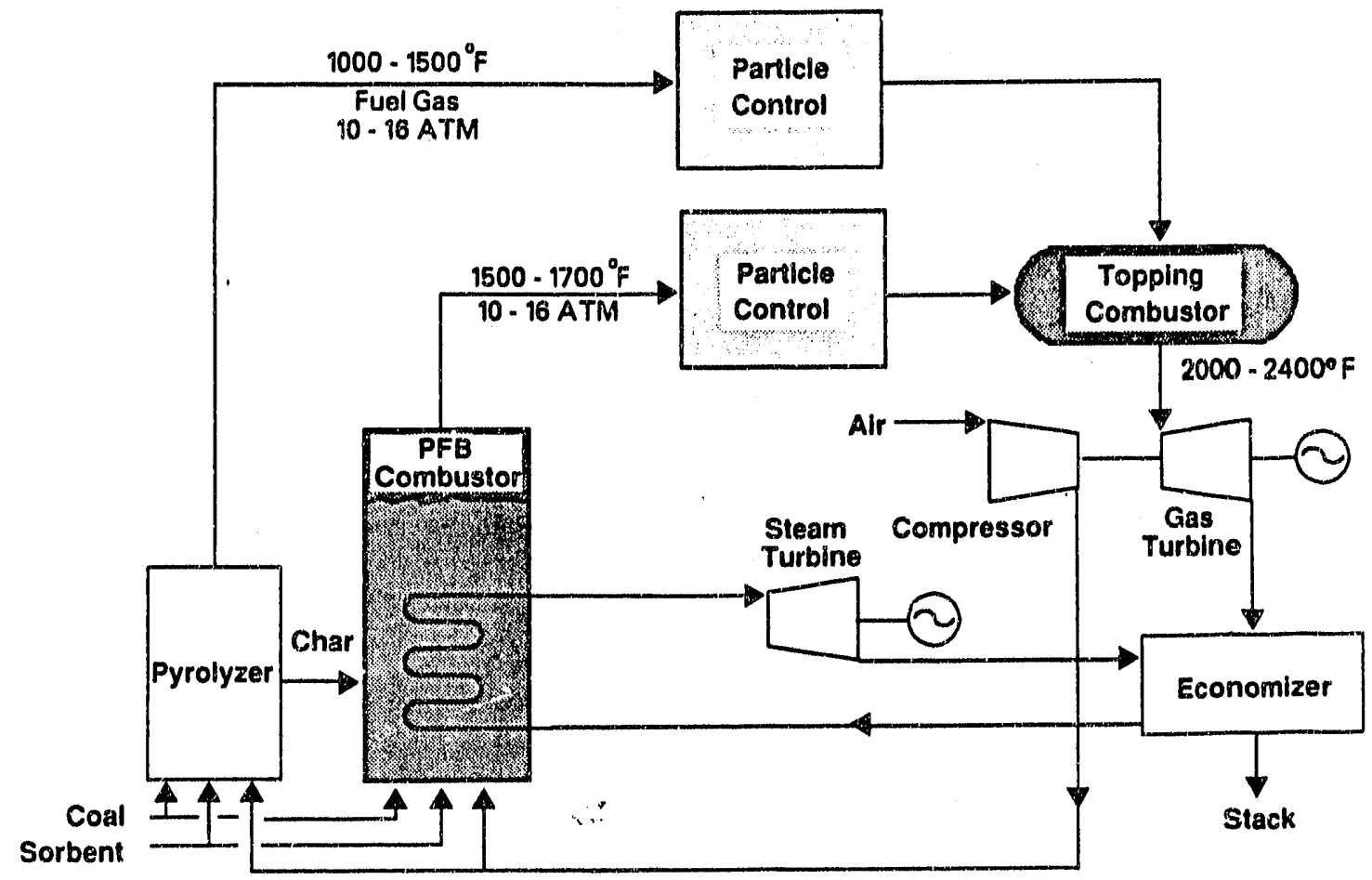

Second Generation

M91001335

Iigure 1. Pressurized Fluidized-Bad Combustion Systans 


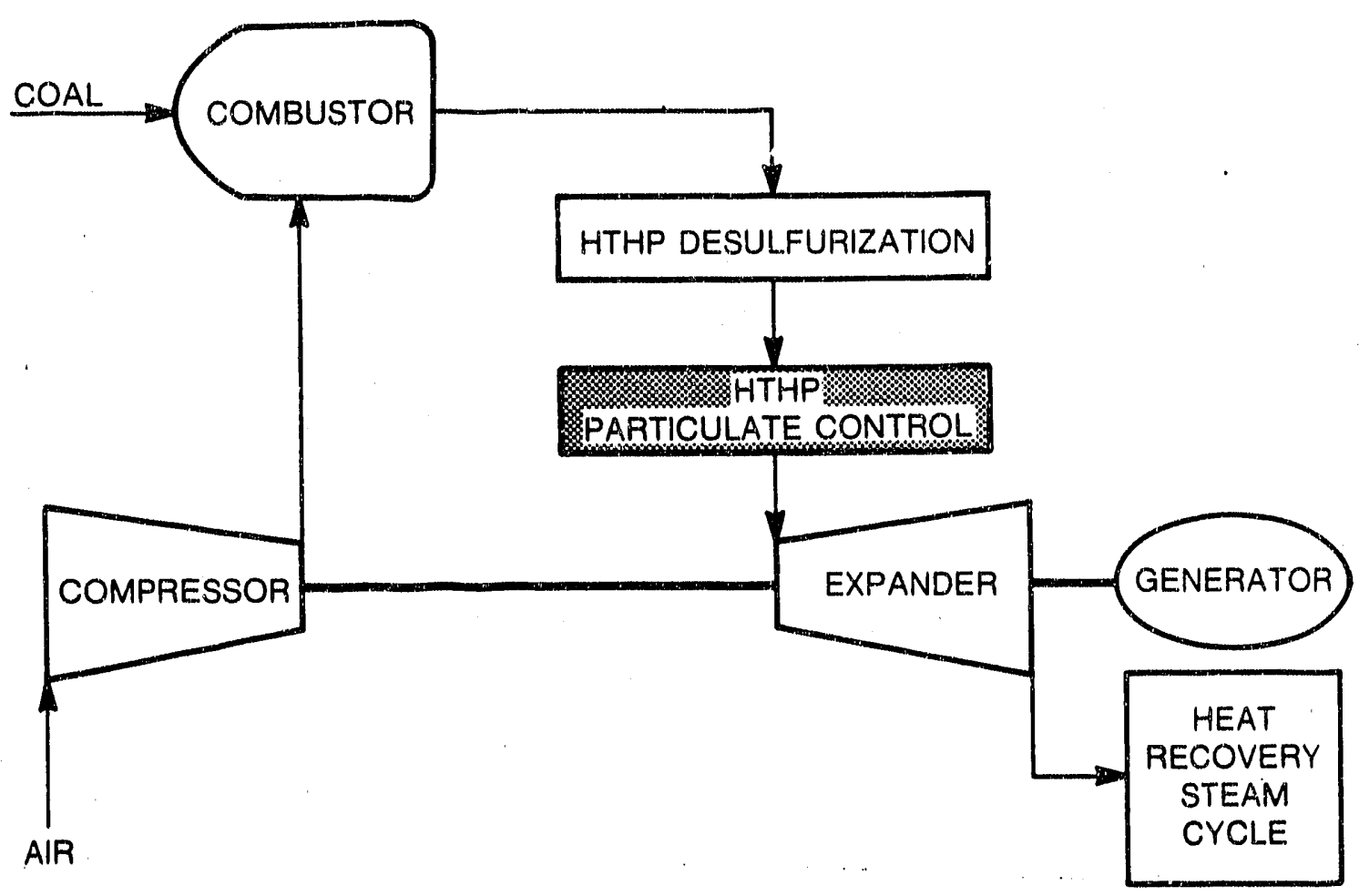

M91000574

\section{Figure 2. Direct Coal-Fualed Turbine System}

between the combustor and the turbine. Depending on the specific DCFT system, contaminants neer to be removed at temperatures between 982 and $1,232^{\circ} \mathrm{C}\left(1,800\right.$ and $\left.2,250^{\circ} \mathrm{F}\right)$ and at pressures from 0.93 to $3.55 \mathrm{MPa}$ (135 to $515 \mathrm{psia}$ ). Particles and sulfur, nitrogen, and alkall compounds axe the contaminants of major concern in DCFT systems. Some DCFT systems contain both reducing and oxidizing zones of gas, which provide distinct opportunities for control of contaminants. The major advantages of a DCFT system are its simplicity and its potential for using a wide range of fuels. Energy conversion efficiencies as high as 50 percent may. be possible in DCFT systems.

\subsection{Integrated Gasification Combined-Cycle (ICCC) systom}

Figure 3 shows the general arrangement of a simplified IGCC system. For power yeneration from Coal, IGCC systems promise to be an efficient and economical route for nodular power plants. Total energy conversion efficiencies for IGCC systems are projected to approach 50 percent. Gas turbines coupled with coal gasifiers can be implemented as modular power blocks into a total system. 


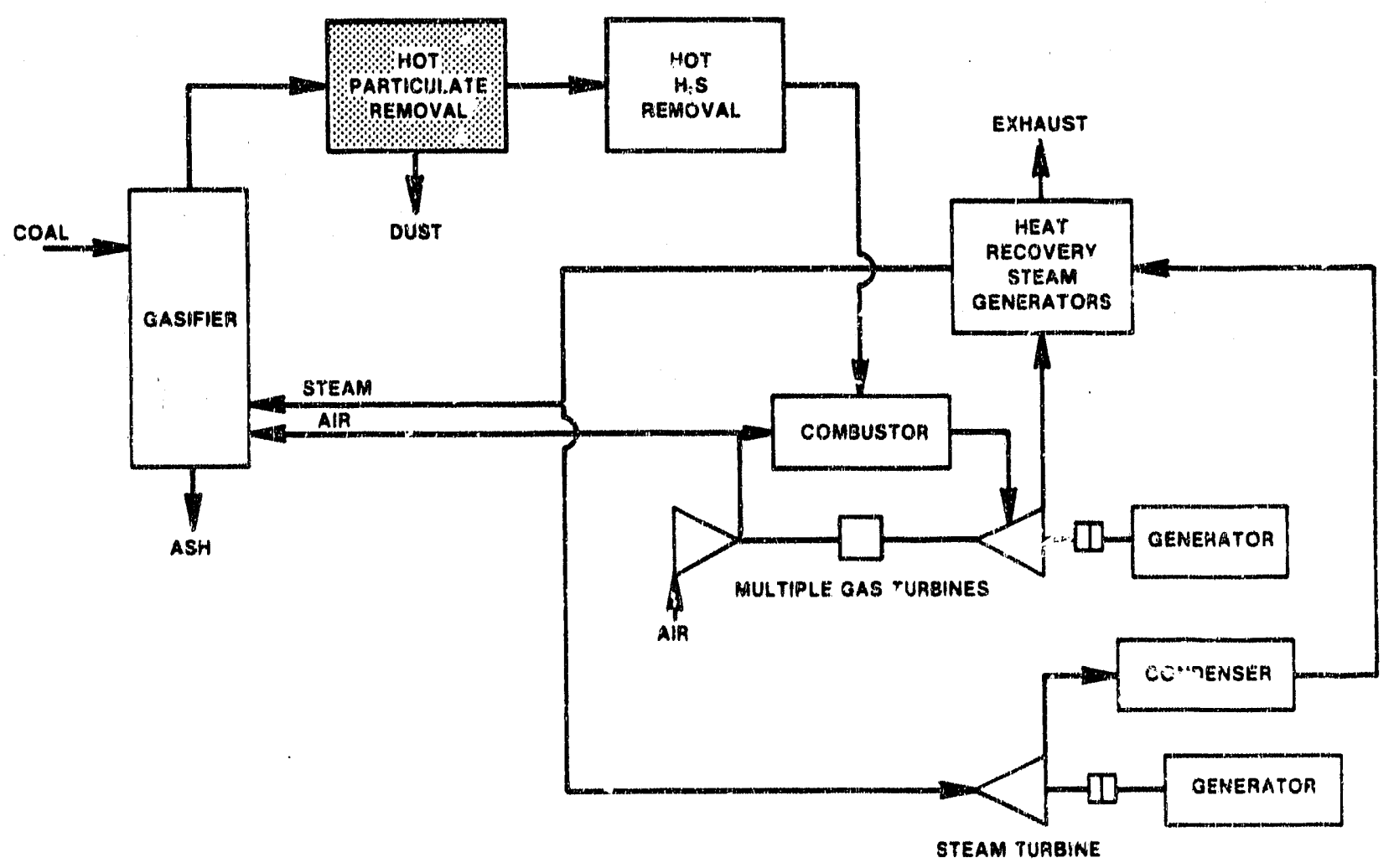

M91000575

Figure 3. Intagratad Ganificmeion Combinad-Cycle Systam

These modules can be fabricated in the shop and assembled in the field. In the IGCC system, the gaeifier converts the coal into a gaseous fuel by reacting it with air and steam. Rarticles and chemical contaminants muet be removed from the fuel gas before the gas is combusted and expanded through the gas turbline. To preserve system efficiency and reduce capital costs, the gasification systems attempt to match the operating conditions of the gasifiex, the contaminant control processes, and the gas turbine. Removing contaminants prior to combustion results in a decreased volume of gas that must be processed and an increased concentration of contaminants. As a consequence, the contaminant control technologies integrated in coal gaslfication systems are smaller and operate with higher removal efficiencies when compared with contaminant corizrol technologies integrated in conl combustion systems.

\subsection{Gagification/Eugl Call system}

The two primary gasification/fuel cell systems that are under investigation are the MCFC and sOFC systems (rigure 4 ). In 


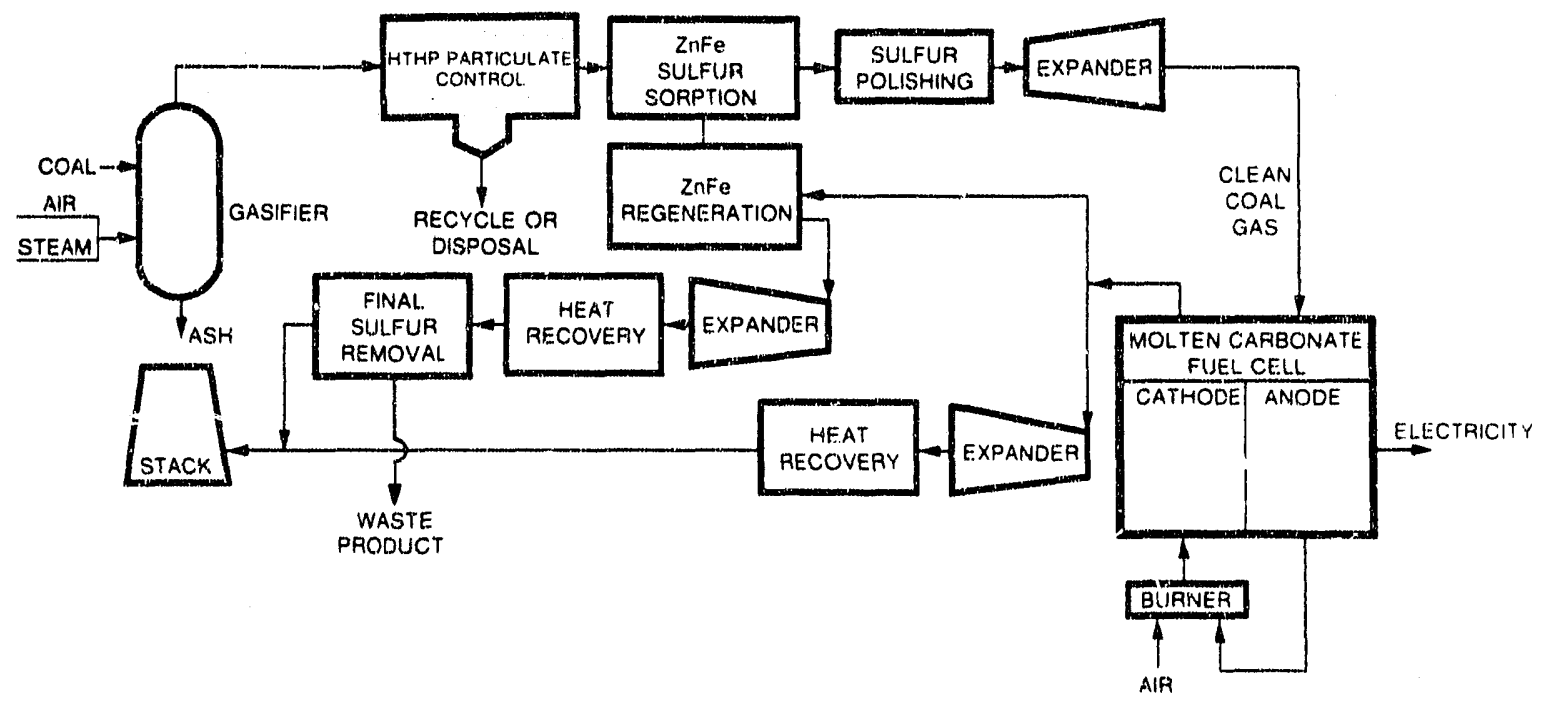

Molten Carbonate Fuel Cell System

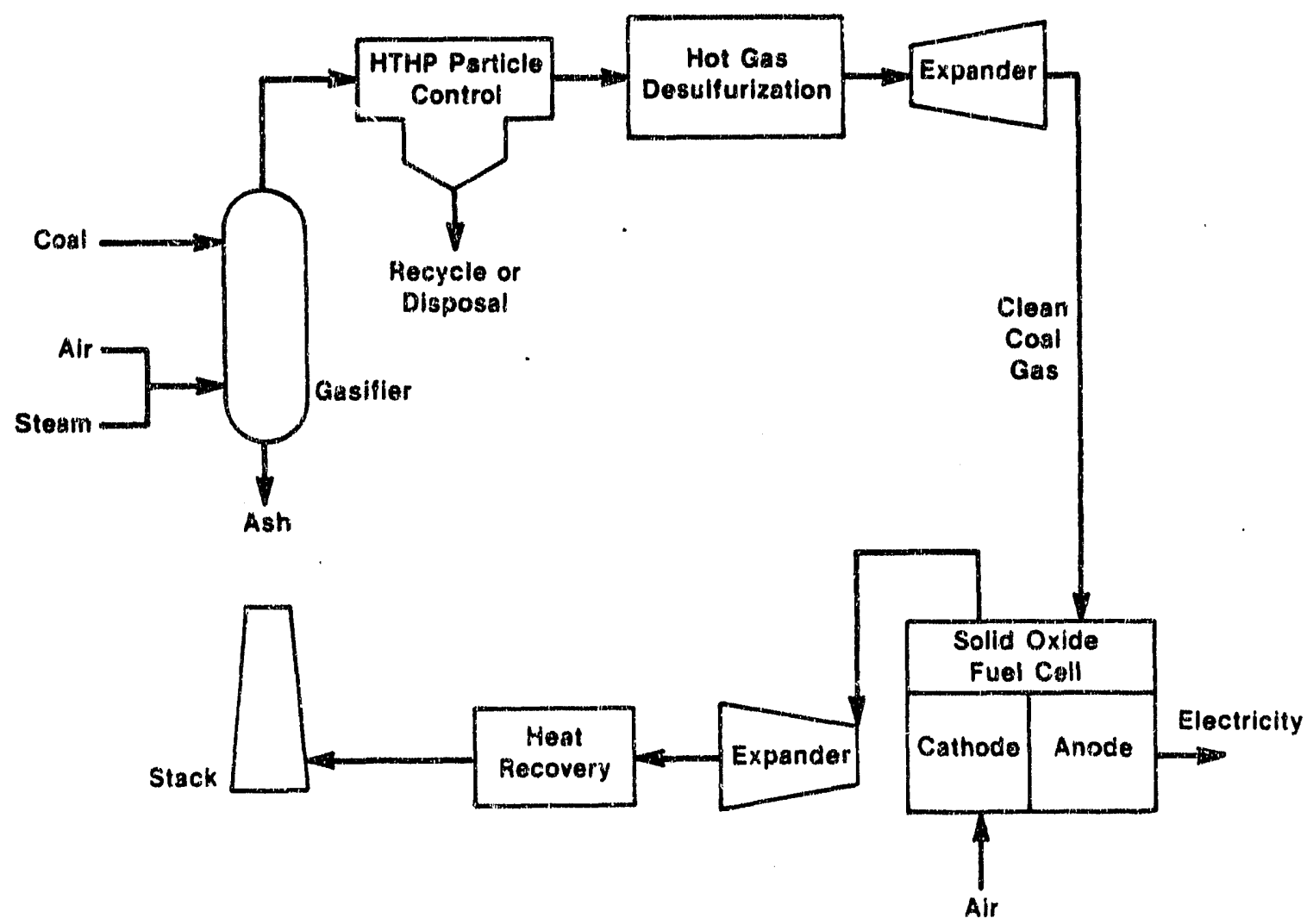

Solid Oxide Fuel Cell System

Eigure 4. Gasitier/fuld Colds systems

M91000570 
both fuel cell systems, hydrogen and carbon monoxide in the fuel gas are corsumed to produce electricity. A fuel cell consists of two electrodes, the cathode and the anode, separated by an electrolyto. Fuel gas from a coal gasifier is fed to the anode where it is oxidized, while an oxidant (air) is fed to the cathode, whare it is reduced. Electrons liberated by the oxidation reaction at the anode are conducted through an outer circuit to the cathode for the reduction reaction; the electron flow through the outer circuit produces direci-current electricity. Contaminants, such as particles, sulfur compounds, nitxogen compouncis, alkali compounds, and trace contaminants, must be removed from the fuel gas before it enters the fuel cell to prevent clogging of the gas passages in the anode and poisoning of the electrodes. To optimize the energy conversion efficiency, these systems attempt to match the operating conditions of the gasifier, contaminant control processes, and the fuel cell. The MCFC operates at a temperature of $649^{\circ} \mathrm{C}\left(1,200^{\circ} \mathrm{F}\right)$ and a pressure of 0.72 to $1.14 \mathrm{MPa}$ (105 to $165 \mathrm{psia}$ ). The sOFC operates at near-atmospheric pressure and a temperiture of $982^{\circ} \mathrm{C}\left(1,800^{\circ} \mathrm{F}\right)$. Studies on SOFC technology are underway to determine if operation at elevated pressures will benefit the SOFC. The total energy conversion efficiencies for MCFC and SOrC systems are expected to exceed 50 percent.

\subsection{Coal-Fueled Diesel (CFD) System}

Operation of diesel engines with coal-based fuels offers a potential economic advantage by replacing conventional diesel fuel with a relatively low-cost fuel that is derived from coal. Coal-based fuels being considered for use in diesel engines include coal slurries, micronized coal, coal-derived liquids, and gaseous fuels. These coal-based fuels could be supplied singly or in various combinations to the diesel engine. Diesel applications include small stationary power plants, industrial cogeneration applications, locomotive applications, and marine applications. Figuxe 5 depicts a conceptual CrD system. Contaminant control strategies are being developed to mitigate emissions of soot, particles, $\mathrm{SO}_{2}$ and $\mathrm{NO}_{x}$.

\subsection{Mild Gasification (MG) System}

Mild gasification systems generate multiple products by devolatilizing coal under moderate conditions of temperatiure and pressure (Figure 5). The products are classified as hydrocarbon liquids, combustible gas, and chars. The initial products from coal devolatilization are upgraded by applying advanced separation techniques, new catalysts, and unique treatment schemes. The applications for the products of MG systems are broad and 


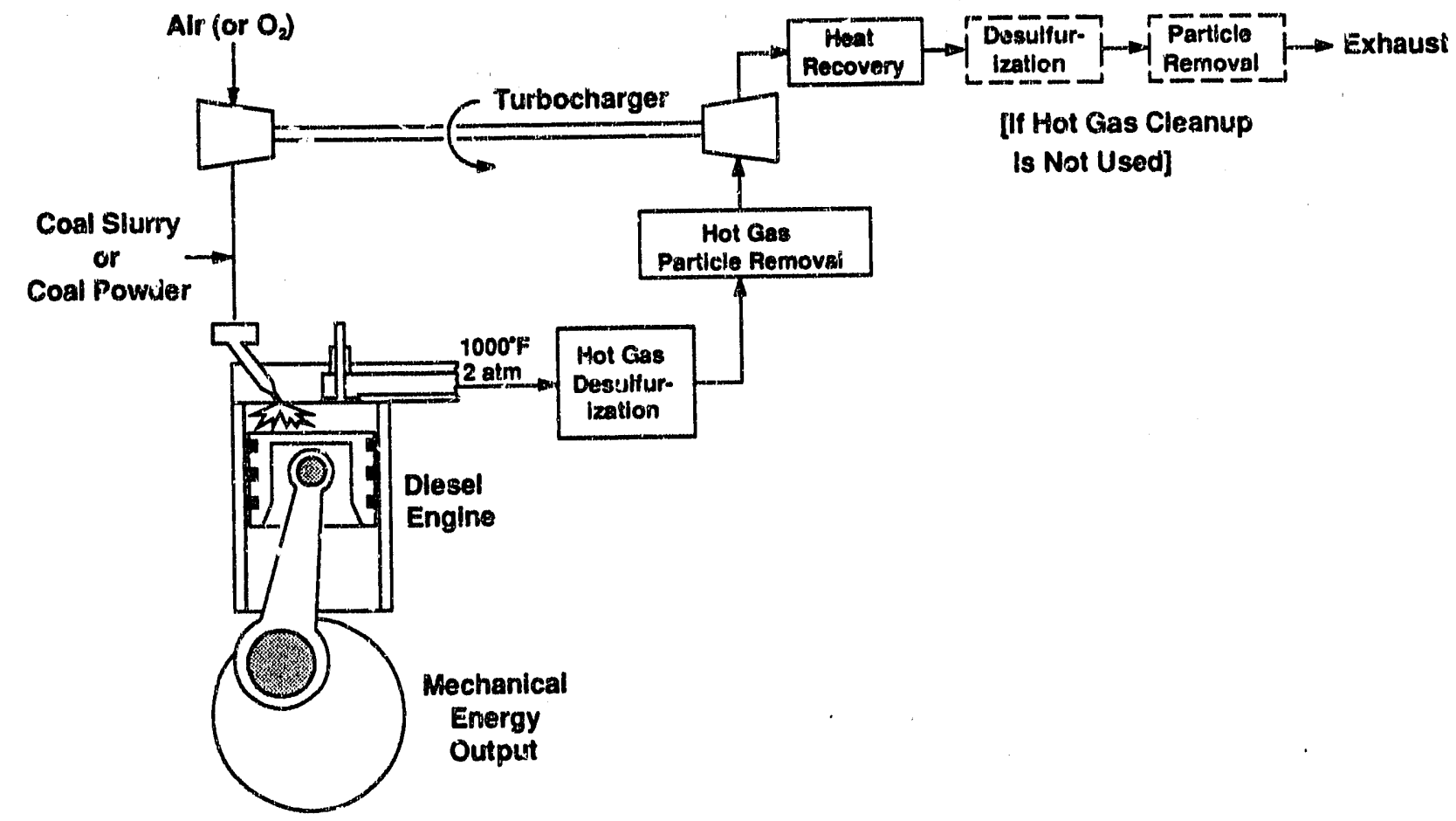

$M 91003500$

Bigure 5. Coal-Fualed Diesel syatem

include electricity generation, industrial chemicals, and transportation fuels. However, contaminants such as particles, sulfur compounds, nitrogen compounds, alkali compounds, and trace contaminants detract from the usefulness of the generated products. MG systems can use fixed-bed, fluidized-bed, and entrained-bed reactors. The contaminant control requirements will likely differ for eaci type of mild gasification system. 


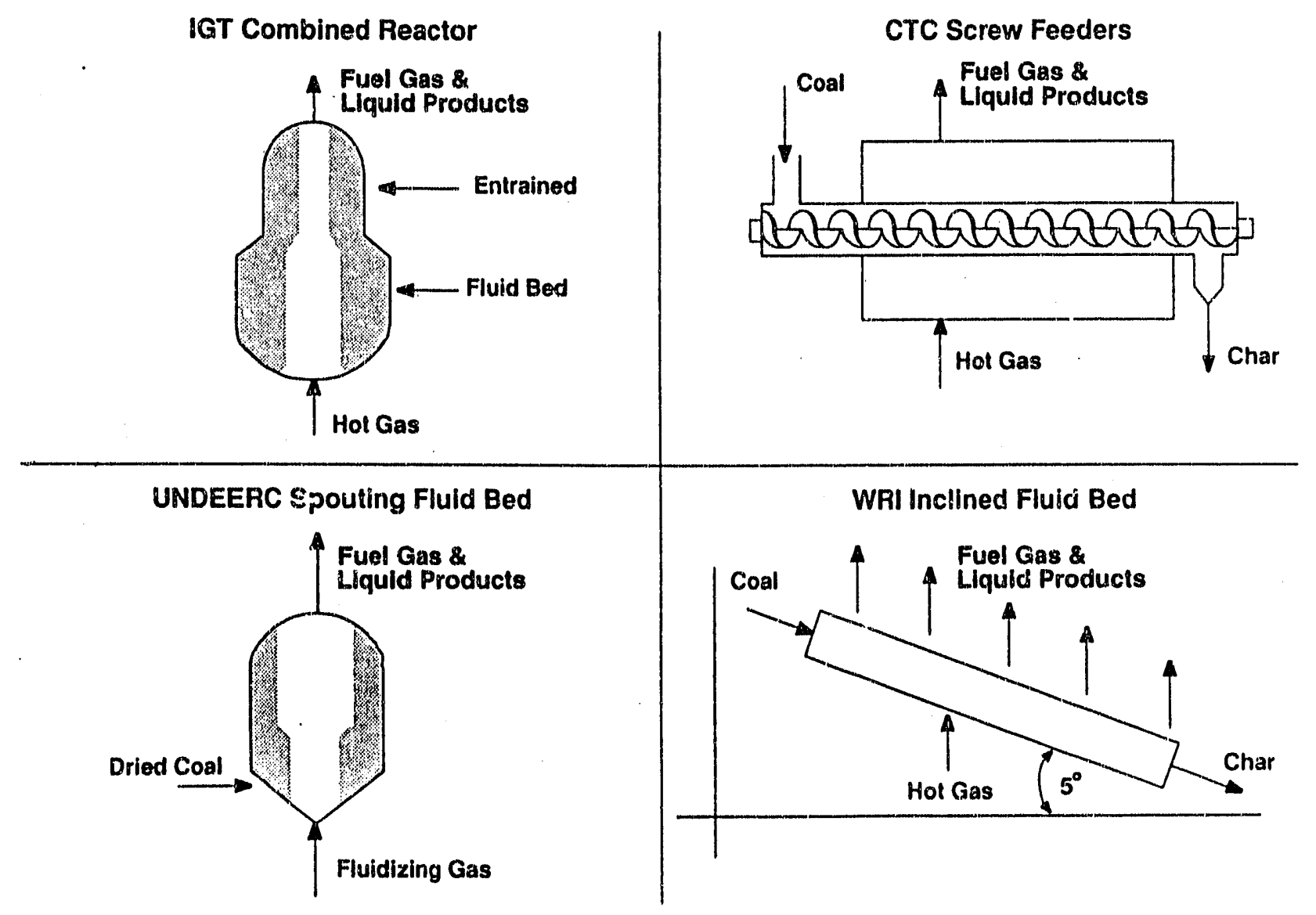

M91000708

Figur. 6. Mild Gairication Proceas Reactors 


\subsection{GAS STREAM CLIFANUR STATUS AND ASSESSMLENT}

\subsection{Gas Stream Cleanue for Pressurized Fluidized-Bed Coubustion Systems}

\subsubsection{Status}

Gas stream cleanup activities in pressurized fluidized-bed combustion systems are focused on characterization and control of particles (Bossart 1989a, 1989b) and alkali compounds (williams and Cicero 1988). Typical operating conditions and contaminant control goals for PFBC systems are shown in Table 1. In-bed desulfurization using calcium-based sorbents reduces sulfur to levels meeting current environmental regulations. Emissions of $\mathrm{NO}_{x}$ are low because of limited thermal $\mathrm{NO}_{x}$ generation at the relatively low combustion temperatures of PFBC systems.

Table 1. Contaminant Control Goala and Operating Conditions in RHBC systom

\begin{tabular}{|c|c|}
\hline $\begin{array}{c}\text { Operating Farameter } \\
\text { Contaminant }\end{array}$ & $\begin{array}{c}\text { Operating Condition/ } \\
\text { Control Goal }\end{array}$ \\
\hline Temperature & 816 to $927^{\circ} \mathrm{C}\left(1,500\right.$ to $\left.1,700^{\circ} \mathrm{F}\right)$ \\
\hline Rressure & 0.79 to $1.76 \mathrm{MPa}$ (115 to $255 \mathrm{psia}$ ) \\
\hline Particles & Lower than NSPS ${ }^{1}$ \\
\hline Particle Size & No particles > 5 to 12 micrometers $(\mu \mathrm{m})$ \\
\hline Sulfur & $\begin{array}{l}\text { Lower than NSPS for } \mathrm{SO}_{2} \text { emissions; } \\
\text { Controlled with in-bed sorbents }\end{array}$ \\
\hline A.lkali & $<0.024$ ppmw \\
\hline Ammonia (Nitrogen) & $\begin{array}{l}\text { Lower than NSPS for } \mathrm{NO}_{2} \text { emissions; } \\
\text { Controlled without hot gas cleanup }\end{array}$ \\
\hline $\begin{array}{l}\text { Halogenated } \\
\text { Compounds }\end{array}$ & Controlled without hot gas cleanup \\
\hline $\begin{array}{l}1 \text { NSPS for particle } \\
\left(0.03 \mathrm{mb} / \mathrm{MBtu}^{2} \text {. }\right. \\
\text { NSPS for } \mathrm{SO}_{2} \text { einissi } \\
\text { reduction, except } 7 \\
<259 \mathrm{mg} / \mathrm{MJ}(0.6 \mathrm{~b} \\
3 \text { NSES for nitrogen } \\
\text { (0.6 1b/MEtu) and } 6\end{array}$ & $\begin{array}{l}\text { emissions is } 13 \mathrm{mg} / \text { megajoule (MJ) } \\
\text { ions is } 517 \mathrm{mg} / \mathrm{MJ}(1.2 \mathrm{lb} / \mathrm{MBt} \text { ) and } 90 \% \\
70 \% \text { reduction if } \mathrm{SO}_{2} \text { emissions are } \\
\text { b/Mtu). } \\
\text { dioxide }\left(\mathrm{NO}_{2}\right) \text { emissions is }<259 \mathrm{mg} / \mathrm{MJ} \\
658 \text { reduction. }\end{array}$ \\
\hline
\end{tabular}


Particle Control

Advanced partinle control technologies are needed in PFBC systems to protect the gas turbine and to meet envirormental regulations. Advanced particle control technologies being developed for PEBC applications include the ceramic cross-flow filter (Lippert et al. 1990), ceramic candle filter, screenless granular bed filter (Wilson and Haas 1990), acoustic agglomeration (Koopman and Reethof 1939), and nested fiber filter (Conkle and Litt 1988; Isitt and Conkle 1990).

Ceramis Crosa-glow Filtur. Significant improvements have been made in the design and manufacture of the ceramic cross-flow filter (Figure 7): improved sealing materials; reduced stresses in channels and flange; novel method for maintaining the filter element in compression during operation; and improved characterization methods for filter qualification. Recent ceramic crossflow filter tests under PFBC conditions included evaluations at the KRW-PFBC simulator facility (Lippert et al., Bench-Scale Coal Gasifier, 1989), the NYU subpilot-scale PEBC facility (Lippert et al., Pressurized Fluid Bed Coal Gasifier, 1989), and the Westinghouse PFBC simulator facility (Lippert et al. 1990).

An eight-element, cross-flow filter system was tested for 160 hours at the KRW-PFBC simulator facility using re-entrained PEBC fly ash. Nominal test conditions were temperatures of 843 to $885^{\circ} \mathrm{C}\left(1,550\right.$ to $\left.1,625^{\circ} \mathrm{F}\right)$, pressures of 0.54 to $0.79 \mathrm{MPa}$ (78 to 115 psia), inlet particle loading of 1,000 to 2,000 ppmw, average filtration velocities of 0.021 to $0.031 \mathrm{~m} / \mathrm{s}(4.3$ to $6.1 \mathrm{ft} / \mathrm{min})$, and a baseline pressure drop of 4.2 to $8.7 \mathrm{kilopascals} \mathrm{(kPa)} \mathrm{(17}$ to 35 inches of water column $\left.\left[{ }^{\mathrm{p}} \mathrm{H}_{2} \mathrm{O}\right]\right)$. The particle loading at the outlet of the cross-flow filter system was consistentiy less than 10 ppmw. Post-test inspection of the ceramic cross-fiow filter system revealed that two of the eight filter elements experienced cracks, which leaked minor quantities of dust into the clean gas plenum. The other six filter elements showed no structural failures. The two cracked filter elements did not detrimentalily affect the overald performance of the cross-flow filter system as evidenced by an avexage outlet dust loading of less than 5 ppmw. An improved id-rib bond design, coupled with a compressive mounting axrangement with ceramic rods, probably inhibited catastrophic delamination of the filter elements.

A 15-element, ceramic cross-flow filter system was tested at the NYU subpilot-scale PFBC facility (Lippert et al. In press). Nominal test conditions were temperatures of 704 to $816^{\circ} \mathrm{C}(1,300$ to $\left.1,500^{\circ} \mathrm{F}\right)$, pressures of $0.83 \mathrm{MPa}(120 \mathrm{psia}$, and inlet particle loadings of 250 to 1,060 ppmw. For the first 50 -hour test, the ceramic cross-flow filter system was operated at a nominal filtration velocity of $0.026 \mathrm{~m} / \mathrm{s}(5.2 \mathrm{ft} / \mathrm{min})$ with a baseline 


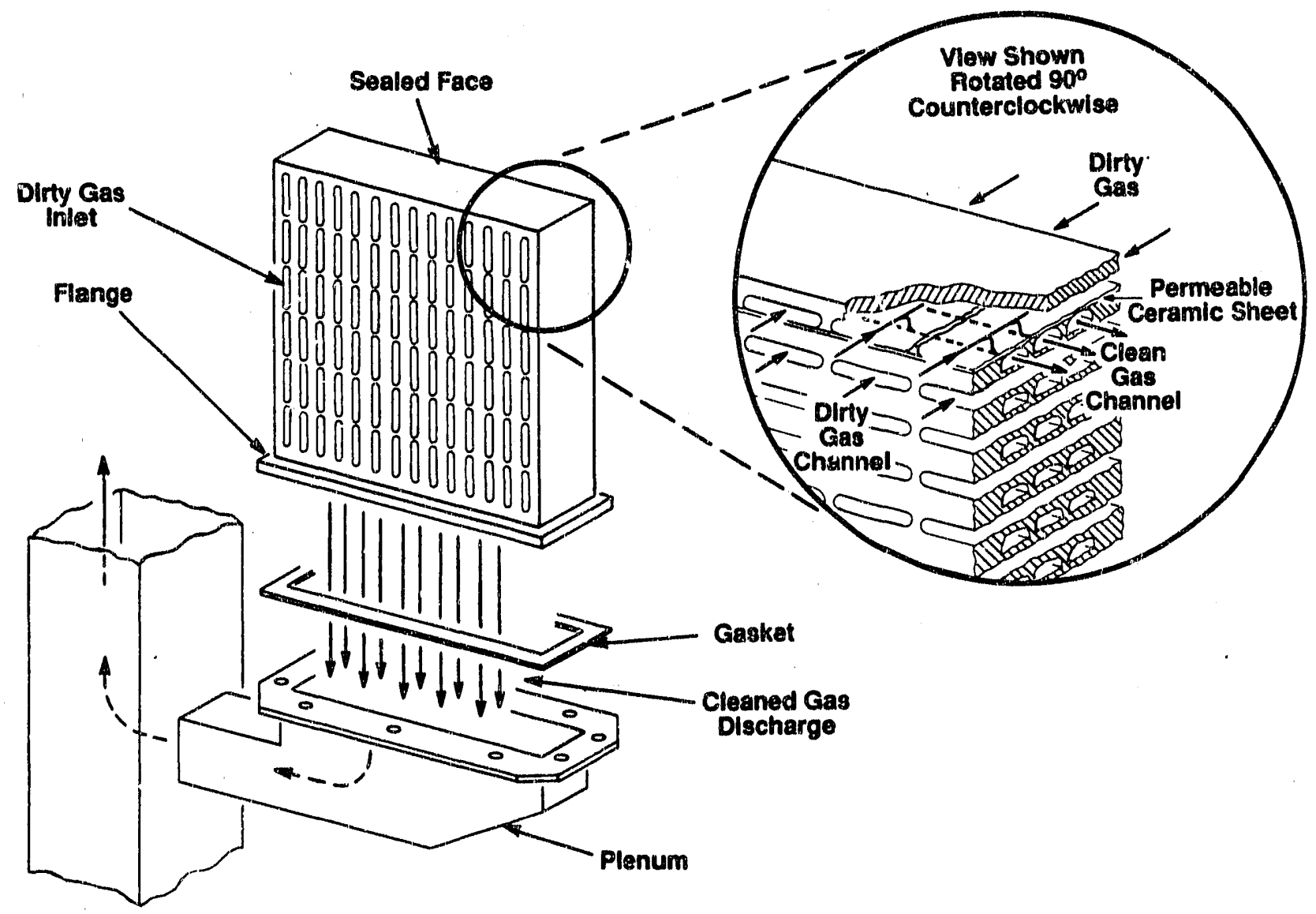

M91001334

Figure 7. Cexamic Cross-Flow riltar

pressixs drop of $8.7 \mathrm{kPa}\left(35 \mathrm{H}_{2} \mathrm{O}\right)$. The particle loading at the outlet of the cross-flow filter system ranged from 3 to 9 ppmw. post-test inspection revealed that the bottom filter element in one module had experienced a small flange crack on the side of the clean gas channels. This filter element was removed from service for the next test. Eiguxe 8 shows that the ceramic cross-flow filter system was able to meet NSPS for particle emissions and particle tolerance limits for gas turbines.

For the next test, the ceramic cross-flow filter system was operated at a nominal filtration velocity of $0.051 \mathrm{~m} / \mathrm{s}$ (10 ft/min) with a baseline pressure dxop of $19.4 \mathrm{kPal}\left(78 \mathrm{H}_{2} \mathrm{O}\right)$. For the first 11 hours of testing, the particle loading at the outlet of the ceramic cross-flow filter was less than 14 ppmw, but increased to $103 \mathrm{ppmw}$ during the next 19 hours. Solenoid valves on the pulse cleaning system and a sorbent feed valve failed during this test. The test was voluntarily terminated to determine the cause of the high particle loadings at the outlet 


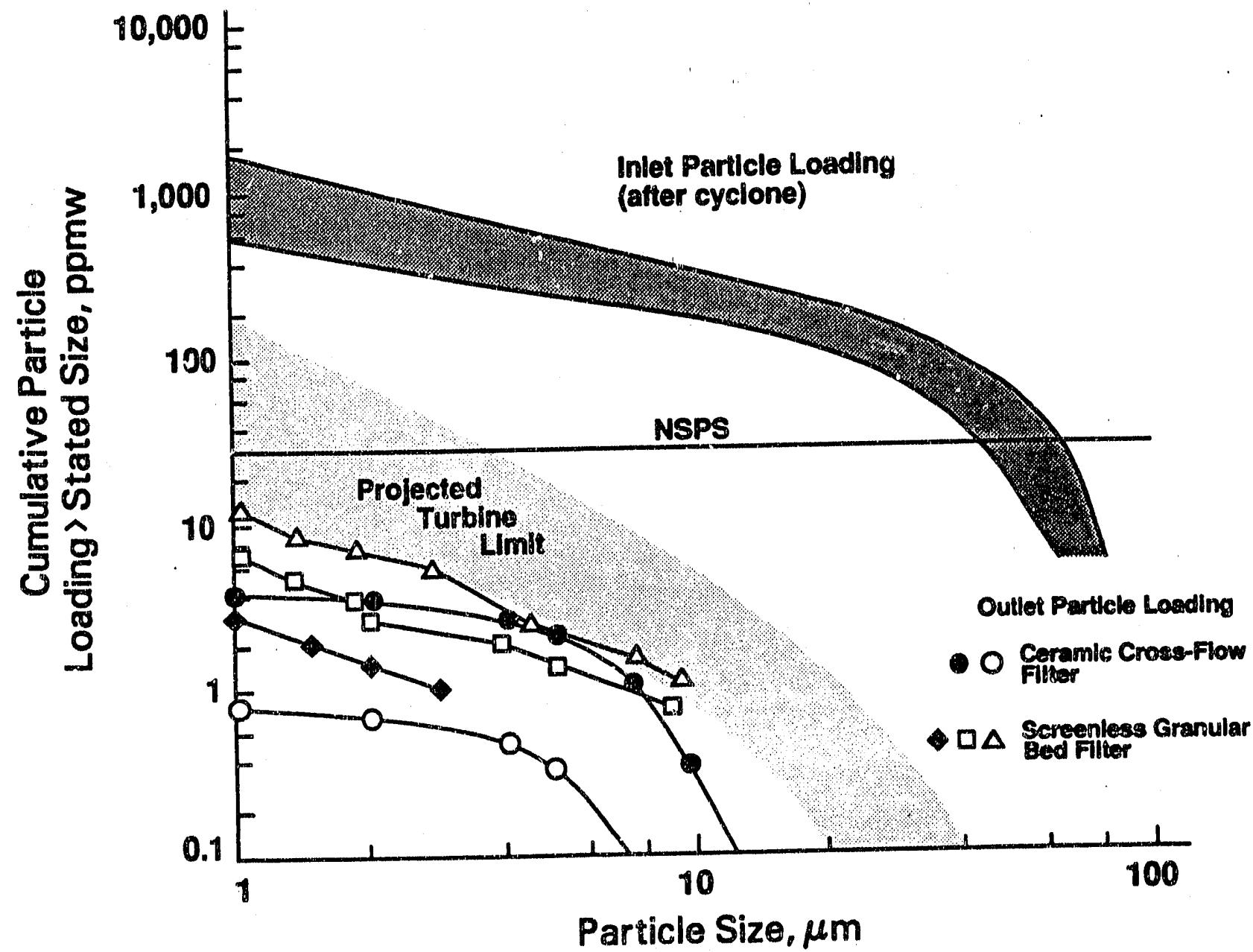

M91001333

Jigure 8. Rexformance of Cermic Cross-riow Eilter and Screenles Granular Bed Filter at NYU PIBC

of the cross-flow filter system. A post-test inspection of the ceramic cross-flow filter system revealed that the major cause of the particle penetration was due to failed dust seals, which were installed betwien the filter body and the mounting flange.

Two ceramic cross-flow filters are being tested for over 2,000 hours of operation at the Westinghouse PFBC simulator (Lippert et al. 1990; Smeltzer, Lippert, and Bachovchin 1990). The purpose of this test is to evaluate the lorg-term durability and filtration characteristics of the ceramic cross-flow filter. Both of the cross-flow filters developed a cracked flange after approximately 1,300 hours of operation. The outlet particle 
loading was less than 2 ppmw prior to development of the cracked flange. The test was discontinued when the outlet particle loading gradually increased to 30 ppmw during the last 160 hours of operation. Testing will be resumed after completing a thorough assessment of the filter failure.

The ceramic cross-flow filter is being evaluated as an advanced particle filter for second generation PFBC applications In this application, advanced particle filters are needed to control particles in the fuel gas from the partial gasifier and in the exhaust gas from the PFBC. Westinghouse has constructed and operated a cold-flow model of a ceramic cross inlow filter system for a second generation PFBC system. They are observing the gasparticle flow patterns within the ceramic cross-flow filter vessel to identify designs, which minimize re-entrainment of particles and encourage downflow of the gas.

Ceramic Candle rilter. The size distribution of particles in the gas is known to significantly affect the filtration and cleaning characteristics of ceramic barrier filters (i.e., ceramic candle, cross-flow, and tube). Tests using gas from a coalfired, atmospheric fluidized-bed combustor were conducted at METC. to evaluate the effect of particle concentration and size distribution on the filtration properties of the candle filter (Chiang et al. 1990; Dennis, Strickland, and Chiang 1990). Results indicated that a relatively modest reduction in mean particle size of 63 percent (i.e., from 11.4 to $4.2 \mu \mathrm{m}$ ) increased the flow resistance across the dust cake by a factor of 20 . These results suggest that both large and small particles are needed to form a filter cake with characteristics that result in a reasonably low pressure drop across the ceramic barrier filter system. The cyc.".one system upstream of the ceramic barrier filter needs to be carefully desigred to ensure that particles with an optimal size distilibution are received at the ceramic filter.

Screenles Granular Bed Filter. A screenlese granular bed filter concept has been under development by Combustion power Company since the 1970's. The screenless granular bed filter (Figure 9) was successfully tested for 164 hours during three test periods at the NYU PEBC facility (Wilson and Haas 1990; Zakkay et al. 1988). A media size of 2-mm (0.079-in) diameter was used during the first two test periods, while a $3-\mathrm{mm}$ (0.118-in) diameter media was used during the third test. The filtration velocity during the first two tests was 0.15 to $0.18 \mathrm{~m} / \mathrm{s}$ (30 to $36 \mathrm{ft} / \mathrm{min})$, while the third test was operated at a filtration velocity of $0.30 \mathrm{~m} / \mathrm{s}(59 \mathrm{ft} / \mathrm{min})$. Tests were conducted at gas temperatures between 843 and $871^{\circ} \mathrm{C}(1,550$ and $1,600^{\circ} \mathrm{F}$ ), pressures of 0.72 to $0.93 \mathrm{MPa}$ (105 to $135 \mathrm{psia}$ ), and inlet particle loadings between 360 and 1,580 ppmw. Outlet particle loadings were consistently less than 20 ppmw and as $10 \mathrm{w}$ as 1 ppmw. Figure 8 shows that the GBF was able to meet NSPS for 


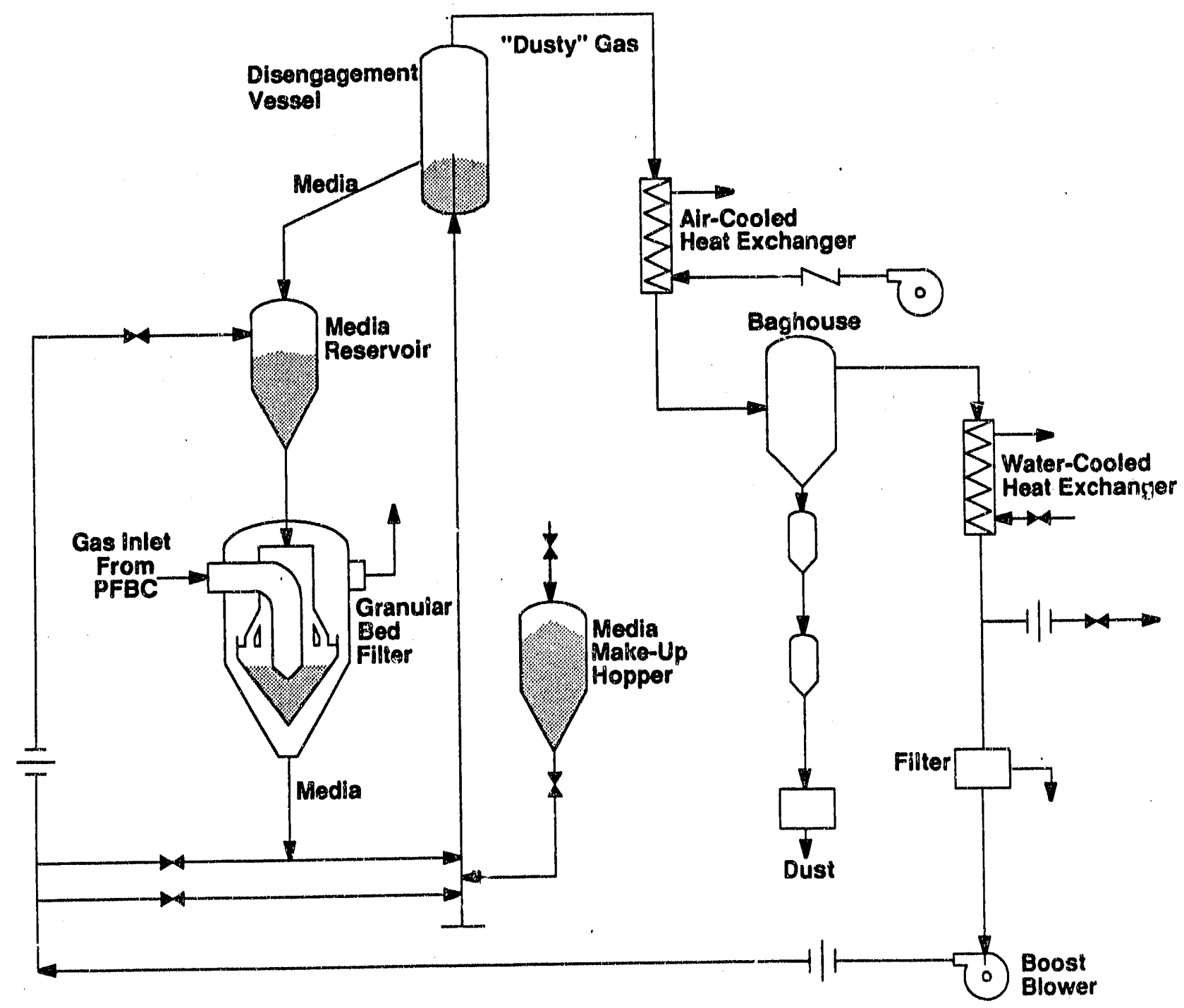

M91000579

\section{Figure 9. Screonles Granular Bed Hiltar System}

particle emissions and particle tolerance limits for gas turbines.

The benefit of using 3-mm media during the third test was to permit the $R F B C$ exhaust gas flow through the filter bed to be increased by about 64 percent. Test results indicate that the 3-mm media was as effective in removing particles as the 2-mm media. The filtration velocity through the filter bed during the second and third tests was about 30 to 35 percent of the minimum fluidization velocity. The use of $3-\mathrm{mm}$ media can result in 3 ubstantial savings in capital cost for a commercial GBF system because fewer filter elements will be required for processing the same quantity of PFEC exhaust gas. Post-test inspection of the 
GBF system at the conclusion of the NYU PFBC test program revealed significant wear of the refractory-lined sections of the lift pipe and the media injection valve area.

Acoustic Agglomeration. Acoustic agglomeration is a pretreatment technique used to shift the size distribution of particles in the gas toward a larger particle size. Following the shift to a larger particle size, the particles are efficiently removed in a conventional cyclone. The Pennsylvania State University conducted several high-temperature, high-pressure (HTHP) acoustic agglomeration tests on re-entrained PFBC fly ash using an acoustic, 2,000-watt siren as the sound source (Koopman and Reethof 1989; Reethof, Koopman, and Dorchak 1.989). Nominal test conditions were temperatures of 427 to $816^{\circ} \mathrm{C}\left(800\right.$ to $\left.1,500^{\circ} \mathrm{F}\right)$, pressures of 0.86 to $1.03 \mathrm{MPa}$ (125 to $150 \mathrm{psia}$, inlet particle loadings of 950 to $4,800 \mathrm{ppmw}$, residence times of 3.5 to 4 seconds, sound pressure levels of 152 to 157 decibels, and sound frequencies of 820 to 910 hertz. In general, more than 30 percent of the particle mass was transferred from the smaller particle sizes (less than $5 \mathrm{\mu m}$ ) to the larger particle sizes (greater than $10 \mu \mathrm{m}$ ) due to acoustic agglomeration.

In 1991, an acoustic agglomeration system will be tested for 200 hours by solar lurbines using a simulated RBBC exhaust gas. Pulse combustors fired with natural gas will generate high intensity sound at selected frequencies to enhance agglomeration of PFBC fly ash. This test will demonstrate, for the first time, the concept of the integrated acoustic agglomeration system consisting of a sound source, agglomeration chamber, and downstream cyclones.

Nosted Fiber Filter. The nested fiber filter consists of a packed bed of interlocking needle-shaped fibers. Filtration occurs when the particles form dendritic or chain-like structures on the nested fibers. Battelle Columbus Division conducted a series of HTHP tests using re-entrained atmospheric fluidized-bed combustion (AFBC) and PFBC fly ash as feed material to the nested fiber filter (Conkle and Litt 1988; Iitt and Conkle 1990). Nominal test conditions were temperatures of 393 to $660^{\circ} \mathrm{C}(740$ to $\left.1,220^{\circ} \mathrm{F}\right)$, pressures of 0.21 to $0.55 \mathrm{MPa}$ (30 to $80 \mathrm{psia}$ ), and filtration velocities of 0.51 to $1.52 \mathrm{~m} / \mathrm{s}(100$ to $300 \mathrm{ft} / \mathrm{min})$. The particle loading at the outlet of the filter was less than 5 ppmw with a relatively low pressure drop of only 1.99 to $7.47 \mathrm{kPa}\left(8\right.$ to $\left.30 \mathrm{H}_{2} \mathrm{O}\right)$. At these low out let particle loadings, the nested fiber filter can meet NSPS for particle emissions and particle tolerance limits for gas turbines.

American Electric Power Service Corporation plans to evaluate integrated engineering designs of ore or two advanced particle control technologies using a $1 / 7$ th-flow slipstream at the Ohio Power Company 70-MWe Tidd REBC facility (Durner and Mudd 
1990). Candidate technologies considered for installation and testing were the ceramic cross-flow filter, the ceramic candle filter, the ceramic tube filter, and the screenless granular bed filter. One or two of these technologies will be tested over a 2-year period from 1992 to 1994, coinciding with planned operation of the Tidd-PFBC under the Clean Coal Technology Demonstration Program. Table 2 provides some of the expected operating conditions for these tests. A ceramic candle filter concept proposed by Westinghouse was selected for testing in 1992. A decision regarding the possibility of testing a second technology will be made by April 1991. These tests will verify the readiness of advanced particle control filters for commercial demonstration in the DOE's Clean Coal Technology Program.

Table 2. Expocted Operating Conditions for Hot Gas Cleanup Teat at Ohio Rowax Company ridd PrBC Plant

\begin{tabular}{|c|c|}
\hline Operating Parameter & Expected Condition \\
\hline Mass Flowrate of Gas & $\begin{array}{l}12.69 \mathrm{~kg} / \mathrm{s}(100,700 \mathrm{lb} / \mathrm{h}, 1 / 7 \mathrm{th} \\
\text { of total flow at Tidd) }\end{array}$ \\
\hline Volumetric Gas Flowrate & $3,641 \mathrm{I} / \mathrm{s}\left(7,715\right.$ actual $\left.\mathrm{ft}^{3} / \mathrm{min}\right)$ \\
\hline Operating Temperature & $852^{\circ} \mathrm{C} \quad\left(1,565^{\circ} \mathrm{F}\right)$ \\
\hline Operating Pressure & $1.14 \mathrm{MPa}$ (165 psia) \\
\hline $\begin{array}{l}\text { Expected Particle Loading } \\
\text { at Inlet of Advanced } \\
\text { Particle Filter }\end{array}$ & 500 to 2,500 ppmw \\
\hline Total rest Period & 7,000 to $8,000 \mathrm{hr}$ \\
\hline
\end{tabular}

\section{Alkwi Compound:}

Alkali compounds, such as potassium chloride (KCl) and $\mathrm{Na}_{2} \mathrm{SO}_{4}$, can contribute to the corrosion of turbine blades and ceramic barxier filters. These alkali compounds can be present in the gas and solid phases. The research program on alkali. compounds has concentrated on development of alkali tolerance specifications for gas turbines, measurement of alkali levels in gasification systems, development of alkali control concepts, and studies involving degradation of ceramic barrier filters by alkali compounds. In general, gas-phase alkali compounds condense or adsorb onto particles in the fuel gas at temperatures below $677^{\circ} \mathrm{C}\left(1,250^{\circ} \mathrm{E}\right)$. At these temperatures, alkali compounds 
may not be a concern if particles are efficiently removed from the system.

Past research under combustion conditions has shown that alumina and alumina silicate sorbents can remove cent of the gas-phase alkali compounds. Most of this work was done under imulated conditions in small fixed-bed reactors where sodium chloride (NaCl) levels wexe reduced from 10 to 0.1 ppmv. Alkali gettering materials include activated alumina, emathlite, hectorite, activated bauxite, and kaolin. Activated bauxite has been developed by Argonne National Laboratory (ANL) as a getter that is regenerated by a simple water wash (Iee et al. 1990).

Injection of emathlite as fine particles in the combustor exhaust gas has removed greater than 99.8 percent of the alkali compounds. The direct injection of emathlite in the fuel gas upstream of a ceramic barrier filter may be required to prevent degradation of ceramic filter naterials. Both Westinghouse and Acurex Coxporation are evaluating the effect of alkali compounds on materials used in construction of ceramic barrier filters.

Ames National Laboratory has developed instrumentation based on atomic emission spectroscopy to measure alkali compounds in a coal-derived gas stream (Williams and Cicero 1988). In 1989, Ames National Laboratory obtained on-line alkali measurements at the ANI PFBC facility (Haas, Markuszewski, and Eckels 1990). These measurements were made downstream of a three-element candle filter system. Particle sampling at the outlet of the candle filter system established that the gas stream had no measurable level of particles. At this location, the sodium content of the gas was 30 to 40 parts per bi i.lion by weight (ppbw), and the potassium content of the gas was 10 to $30 \mathrm{ppbw}$. The alkali. specification for gas turbines of 24 ppbw, as stated in Table 1 , is based on recommendations from turbine manufacturers when firing the gas turbine with petroleum-based fuels. The alkali specification for firing the turbine with coal-derived gas is unknown, but is being evaluated in several large-scale turbine projects sponsored by MC.

\subsubsection{Assesament.}

Contaminant control for PFBC systems has concentrated on development of advanced particle control technologies. The tests at the Grimethorpe RFBC (Leitch and Tassicker 1989) and NYU PFBC facilities demonstrated the technical feasibility of incorporating ceramic cross-flow filters, ceramic candle filters, and screenless granular bed filters into commercial. PFBC systems. These technologies demonstrated their ability to meet environmental regulations for particle emissions and particle tolerance limits for protection of gas turbines. The key technical issues 
regarding incorporation of advanced particle control technologies into PrBC systems involve component durability and reliability. The hot gas test program at the ohio Power Company Tidd PEBC facility will address the reliability, durability, and operational flexibility of the advanced particle control technologies.

Requirements for alkali control in PFBC systems have not been firmly established. Several large-scale turbine projects will study the need for alkali control in PFBC systems.

\subsection{Gen Stream Claanup Ior Direct Conl-yueled Turbino Systems}

The contaminant control requirements and operating conditions (Table 3) in DCFT s.rstems have not been firmly established because DCFT are in the initial stage of development. Westinghouse Electric Corporatiori General Motors, Allison Gas Turbine Division; and Solar Turbines are developing DCF' systems for industrial and utility applications. Novel cleanup methods will be required because of the extremely high operating temperature of DCFT systems (greater than $1,093^{\circ} \mathrm{C}\left[2,000^{\circ} \mathrm{F}\right]$ ). Gas stream cleanup methods are bejng evaluated in both the Heat Engines and GSCU Programs. The Heat Engines Rrogram is adapting existing cleanup methods to DCFT conditions, while the GSCU Program is supporting the development of novel Integrated Low Emission Cleanup (ILEC) concepts (Bedick et al. 1989; webb et al. 1990) for control of particles, sulfur compounds, and alkali compounds in DCFT systems.

\subsection{1 stacus}

\section{IIfHC Concopts}

An initial study of particulate control for DCFT systems was completed in 1987 (Dibella et al. 1987). The objective of this study was to assess the potential of $3 i x$ particulate control. devices for use in DCFT applications. The six particulate control devices assessec wero an electrostatic precipitator, a cross-flow filter, a screenless granular bed filter, a ceramic bag filter, adranced cyclones, and acoustic agglomeration. METC awarded contracts in late calendar year (CY) 1987 to examine three novel IIEC concepts. Contracts were awarded to Westinghouse Electric Corporation, Research-Cottrell (R-C) Environmental Services, and Helipump Corporation.

Westinghouse and $R-C$ have progressed through the technical assessment stage and are currently constructing test facilities to demonstrate their concepts. Research by Helipump Corporation 
Table 3.. Concition and Cleanup coals of the Dixect CoalBired Turbine system

\begin{tabular}{ll}
\hline \multicolumn{1}{c}{ Condition } & Goal \\
\hline Temperature & 982 to $1,234^{\circ} \mathrm{C}\left(1,800\right.$ to $\left.2,250^{\circ} \mathrm{F}\right)$ \\
Rressure & 0.93 to $3.55 \mathrm{MPa}(135$ to $515 \mathrm{psia})$ \\
Uncontrolled Particulate & Undefined \\
Loading (g/scf) & \\
Outlet Particulate & Lower than 1 ppmw for particle \\
Loading & sizes $>5 \mathrm{\mu m}$ \\
Sulfur & Lower than NSPS Limits \\
Alkali & (3) \\
Ammonia (Nitrogen) & (4) \\
Halogen Compounds & (1) \\
(e.g., HCl) &
\end{tabular}

2 Grains per standard chinic foot; these are nominal loadings after one stage of cyclones.

2 At the outlet of the particulate control device.

3 To Be Determined.

4 Controlled without hot gas cleanup.

was discontinued after the initial assessment stage. The hightemperature, electrochemical cleanup concept for $\mathrm{SO}_{2}$ and $\mathrm{NO}_{x}$ control proposed by Helipump was economically unattractive because of requirements for excessive electrical power input.

Westinghouse initially examined three ILEC cleanup concepts (Figure 10). Currently, a test facility is being constructed to evaluate the baseline concept under simulated DCET combustor conditions. Testing will be performed at a pressure of $1.01 \mathrm{MPa}$ $(10 \mathrm{~atm})$ and temperatures ranging from 982 to $1,149^{\circ} \mathrm{C}(1,800$ to $\left.2,100^{\circ} \mathrm{F}\right)$. The baseline concept incorporates sorbent injection with subsequent particle removal by ceramic barrier filters. Considerable research has been conducted by Westinghouse to identify suitable sorbents for control of sulfur and alkali compounds. In addition, sorbent additives have been investigated to reduce particle adhesion to the barrier filter. Iaboratory tests confixned that calcium-based sorbents perform satisfactorily for sulfur capture at DCFT conditions (Newby, Dezubay, and Chamberlain 1987). Emathlite and hectorite, naturally occurring clay minerals, have been identified as effective alkali getters. 


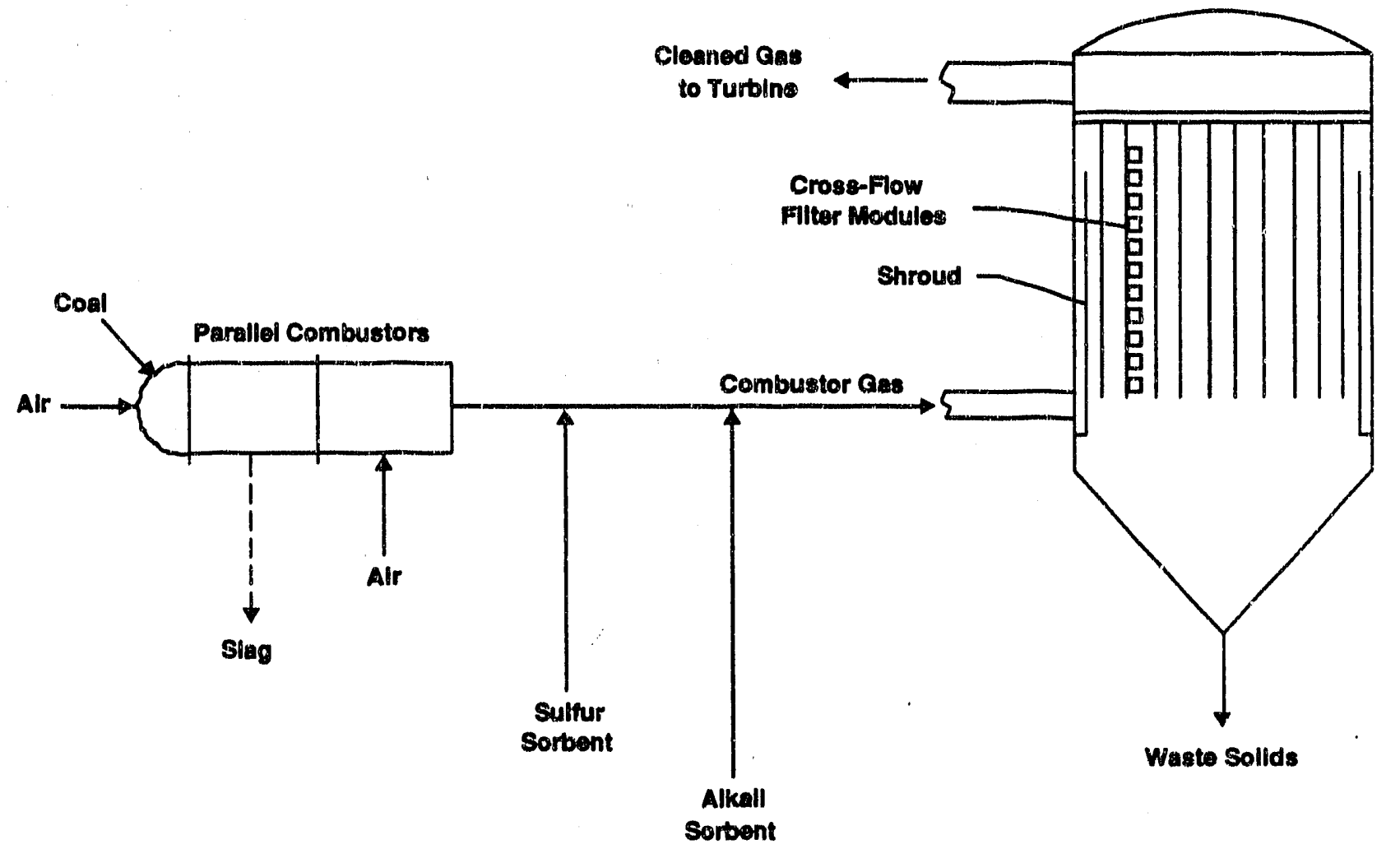

M91000580

\section{Figure 10. Motinghouse IIrC Coxcopt}

Laboratory experiments are underway to assess the fluidized-bed contactor (Figure 10). A cold-flow, fluidized-bed model of a four-element candle filter system was constructed to assess the concept. Research on the moving-bed filter concept has been discontinued because of substantial technical risk when compared to alternative concepts.

R-C Environmental Sciences Division is developing an electrostatic agglomerator (ESA). Figure 11 depicts the concept, in which an electric charge attracts particles toward the plate surface. Particle agglomeration, which is enhanced near the plate surface, shifts the particle size distribution to larger sizes for subsequent removal in hot cyclone. Currently, R-C is construc ing a test facility at KVB Laboratories in California to evaluate their concept. The facilities consist of a $1,054 \mathrm{MJ} / \mathrm{h}$ (1 MBtu/h) coal-water slurry combustor integrated with the bench scale ESA. The ESA will be operated at a pressure of $1.01 \mathrm{MPa}$ (10 atm) and at temperatures up to $1,371^{\circ} \mathrm{C}\left(2,500^{\circ} \mathrm{F}\right)$. 


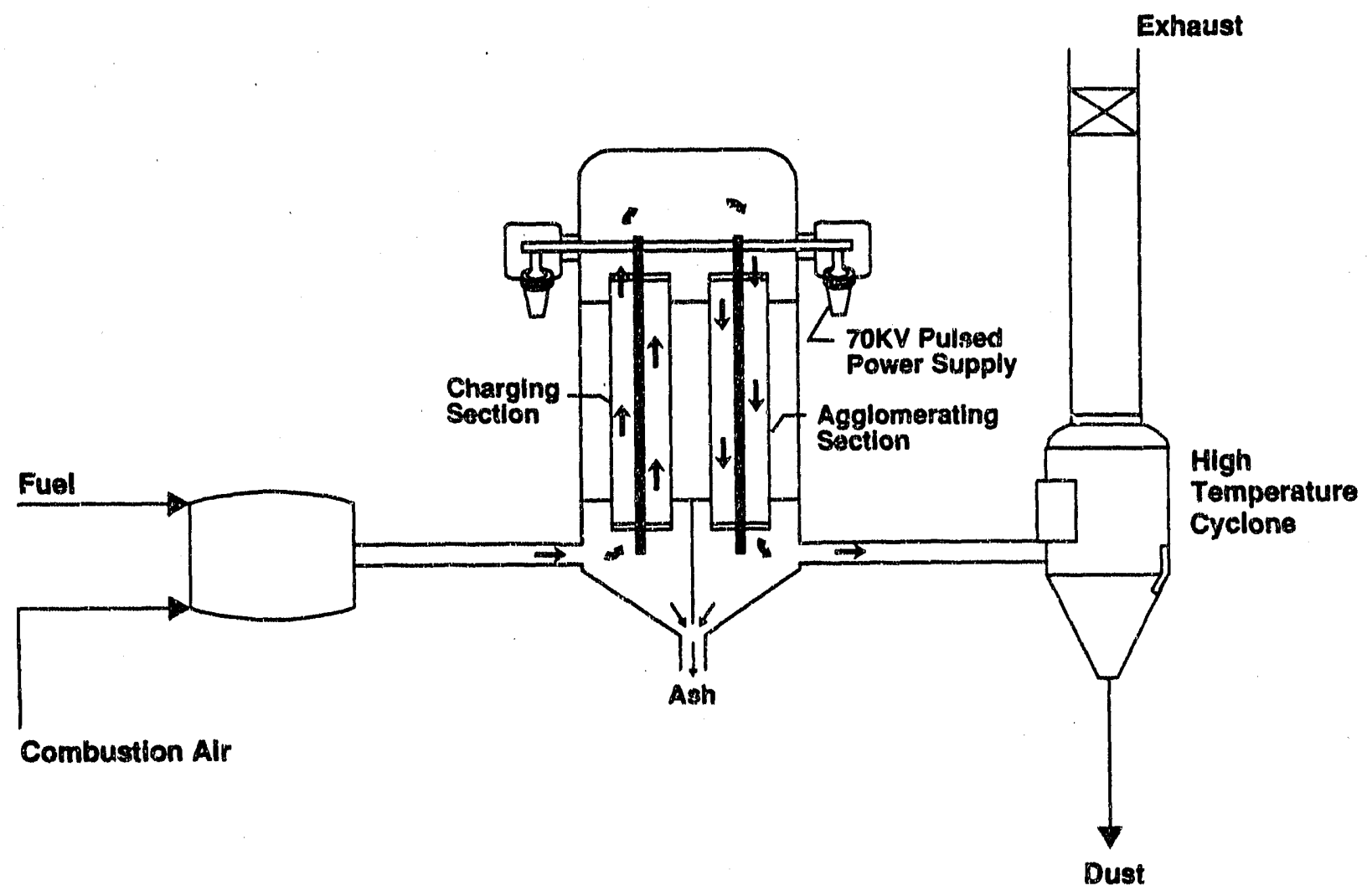

M91000581

Figure 11. Tube Typ Electrostatic Agglomerator

\section{Heat Enginea Program}

The Heat Engines Program is currently operating bench-scale, integrated coal combustors in preparation for tests on full-size subsystems of Advanced Coal-Fired Gas Turbine systems (ACFGTS). Each of these projects includes the development of cleanup systens to control contaminants generated by the combustion of coal. These systems will control polilutant emissions and protect the turbine gas path from fouling, erosion, and corrosion. The subsystem cleanup concepts under development must control $\mathrm{NO}_{x}, \mathrm{SO}_{2}$, alkali compounds, and particles.

The ACFGTS contractors have designed combustors that feature multiple chambers to limit $\mathrm{NO}_{\mathrm{x}}$ formation through staged, richlean combustion. The first combustion stage is operated under fuel-rich conditions and long residence times to convert ammonia to $\mathrm{N}_{2}$, while the second stage is operated under fuel-lean conditions and short residence times to prevent the formation of thexmal $\mathrm{NO}_{x}$. The peak temperature of the second stage is kept below 
$1,538^{\circ} \mathrm{C}\left(2,800^{\circ} \mathrm{F}^{\prime}\right)$ to minimize thermal $\mathrm{NO}_{x}$ formation. NO $\mathrm{NO}_{\mathrm{x}}$ emissions below 66 ppmv have been successfully demonstrated using coal-water slurry fuel (Parsons, Webb, and Zeh 1990; Castleton, Kothari, and Williams 1990).

Reduction of $\mathrm{SO}_{2}$ emissions will be controlled through a combination of fuel beneficiation and desulfurization of the combustion products. Several methods of sorbent injection, such as the Avco Research Iaboratory rapid sulfur capture concept, are under evaluation.

The alkali sulfates $\mathrm{Na}_{2} \mathrm{SO}_{4}$ and $\mathrm{K}_{2} \mathrm{SO}_{4}$ are formed in the combustor when sulfur, sodium, and potassium are present in the fuel. These compounds cause corrosion and rapid wastage of turbine blade materials. The ACFGTS contractors are evaluating various corrosion mitigation strategies including sorbent injection, improved fuel washing procedures, and corrosion-resistant coatings for turbine blades.

Particles must be removed from the gas stream to prevent erosion of the turbine components. Two of the ACEGTS contractors, Allison and Solar, are evaluating a combination of mechanical collectors with ceramic barrier filters to remove particles. Currently, they are testing ceramic candle filters on their bench-scale combustors. Allison will test a candle filter system containing 25 elements, while solar will test a candle filter system containing 14 elements on a slipstream from their benchscale combustor. The team of Westinghouse and Avco plan to use a series of mechanical collectors upstream of the turbine and a post-turbine conventional baghouse downstream of their heat recovery bojler.

\subsection{Assessmant}

Currently, the IIEC concepts are being evaluated at the bench-scale demonstration stage. Two promising concapts under development are the Westinghouse and $R-C$ IIEC concepts. Work has been discontinued on the moving-bed and electrochemical concepts due to their perceived technical risk or projected high cost. During fiscal year (FY) 1991, testing will be performed to identify which of the two ILEC concepts can successfully meet the DCFT cleanup xequirements. The ACFGTS contractors are concentrating on staged combustion for $\mathrm{NO}_{x}$ control, sorbent injection for sulfur and alkali control, and ceramic barrier filters and mechanical collectors for particle control. 


\subsection{Gas Stream Cleanup for Integrated Gasification Combined- Cycle systems}

\subsection{1 status}

Fixed-bed, fluidized-bed, and entrained-bed gasifiers can be used in a simplified IGCC system for power generation (McMichael, Gangwal, and Bossart 1990; METC 1986; Corman 1986). Each of these gasifiers operates under different conditions and generates a fuel gas with its own distinct temperatures, pressures, gas characteristics, and contaminant control requirements. Contaminant control goals and typical operating conditions in IGCC systems are shown in Table 4 .

Tablo 4. Contaminant Control Goals and Operating Conditions in IGCC Systems

\begin{tabular}{|c|c|}
\hline $\begin{array}{c}\text { Operating Parameter/ } \\
\text { Contaminant }\end{array}$ & $\begin{array}{l}\text { Operating Condition/ } \\
\text { Control Goal } \\
\end{array}$ \\
\hline $\begin{array}{l}\text { Gasifier Outlet } \\
\text { Temperature }\end{array}$ & $\begin{array}{l}\text { Fixed Bed: } 427 \text { to } 649^{\circ} \mathrm{C}\left(800 \text { to } 1,200^{\circ} \mathrm{F}\right) \\
\text { Fiuidized-Bed: } 927 \text { to } 1,038^{\circ} \mathrm{C}\left(1,700 \text { to } 1,900^{\circ} \mathrm{F}\right) \\
\text { Entrained-Bed: }\end{array}$ \\
\hline Pressure & 0.93 to $10.33 \mathrm{MPa}$ (135 to 1,500 psia) \\
\hline Particles & Lower than NSPS ${ }^{2}$ \\
\hline Particle Size & No particles $>5$ to $12 \mu^{2}{ }^{2}$ \\
\hline Sulfur & Lower than NSPS for $\mathrm{SO}_{2}$ emissions ${ }^{3}$ \\
\hline Alkali & $<0.024$ ppmw $^{2}$ \\
\hline Ammonia (Nitrogen) & Lower than NSPS for $\mathrm{NO}_{2}$ emissiors" \\
\hline $\begin{array}{l}\text { Halogenated } \\
\text { Compounds }\end{array}$ & Uncertain \\
\hline
\end{tabular}

NSPS for particle emissions is $13 \mathrm{mg} / \mathrm{MJ}(0.03 \mathrm{lb} / \mathrm{MBtu})$.

At inlet of gas turbine.

NSPS for $\mathrm{SO}_{2}$ emissions is $517 \mathrm{mg} / \mathrm{MJ}(1.2 \mathrm{lb} / \mathrm{MBtu})$ and $90 \%$ reduction, except 708 reduction if $\mathrm{SO}_{2}$ emissions are $<259 \mathrm{~g} / \mathrm{MJ}(0.6 \mathrm{lb} / \mathrm{MBtu})$.

NSPS for $\mathrm{NO}_{2}$ emissions is $<259 \mathrm{mg} / \mathrm{MJ}(0.6 \mathrm{lb} / \mathrm{MBtu})$ and $65 \%$ reduction. 
Sulfur control is required for each type of gasifier and can be accomplished by in-bed desulfurization with a calcium-based sorben' and/or externa?. desulfurization using a regenerable, mixed-metal oxide sorbent. In-bed desulfurization is very effective in fluidized-bed gasifiers (graater than 90 percent sulfur removal) (Haldipur, Schmidt, and Smith 1989), but less effective in fixed-bed and entrained-bed gasifiers $(25$ to 60 percent slifur removal). Exterral desulfurization using a regenerable, mixedmetal oxide sorwent, such as zinc ferrite, can achieve greater than 99 percelic sulfur removal for each type of gasifier after adjustment of temperature to the appropriate operating range of the mixed-metal oxide sorbent.

Formation of vapor-phase alkali compounds is mostly a concern in entrained-bed gasifiers and possibly fluidiped-bed gasifiers due to the high temperature of the fuel gar (Bachovchin et al. 1986; Williams and Cicero 1989).

Both fluidized-bed and entrained-bed gasifiers will require advanced particle filters to protect the gas turbine, but cyclone separators may provide adequate particle control in fixed-bed gasification systems.

Ammonia control may be needed in fixed-bed and entrained-bed gasification systems to assist in meeting environmenta? regulations for $\mathrm{NO}_{x}$ emissions (Baker, Roberts, and Mudge 1987; Unnasch 1987).

Tars may require control in fixed-bed gasification systems, but are not a concern in fluidized-bed and entrained-bed gasifiers because tars are decomposed at the high gas temperatures in these systems.

Both the need for contaminant control and the contaminart control scheme are dictated by the type of gasifier, its fuel gas properties, and end-use application. Pilot-scale gasification projects involving testing of hot gas cleanup technologies include programs at the $\mathrm{KR}$ fluidized-bed gasification facility, the Texaco entrained-bed gasification facility, the GE Fixed-bed gasification facility, the Calderon gasification/hot gas cleanup process, and the SCS gasification/combustion facility:

\section{KRW IIuidized-Bed}

The test program at the KRW fluidized-bed gasification facility (Haldipur, Schmidt, and Smith 1989) included evaluations of in-bed desulfurization soxbents, external desulfurization with a racked-bed zinc ferrite gystem, and a ceramic candle filter system. 
In-Bed Desulfurization. In-bed desulfurization with addition of dolomite or limestone at Ca-to-s atomic ratios between 1.2 and 2.6 showed that 85 to 96 percent sulfur reduction was obtainable in the fluidized-bed gasifier. The $\mathrm{H}_{2} \mathrm{~S}$ concentration at the outlet of the gasifier was typically 500 to $600 \mathrm{ppmv}$, which is believed to be elevated dis to excess steam in the gasifier. The excess steam was needed $\ldots$ adjust the gas composition for proper operation of the zinc ferrite system. If the gas composition is overly reducing, the iron oxide component in the zinc ferrite may react with the gas to form iron carbide, which structurally weakens the sorbent.

Mxtexnal Desulfurization. In the KRW test program, a single packed-bed of zinc ferrite sulfur sorbent was tested for a total of 15 sulfidation and regeneration cycles. These tests involved several changes of sorbent material and comprised 950 hours of operation in the sulfidation mode and 500 hours in the regeneration mode. Initial tests were conducted using a cyclone for particle control prior to the sorbent bed and indicated that the resulting particle loading to the bed was intolerable. This was evidenced by development of an unacceptable pressure drop across the bed and Iimited sulfur sorption capacity.

In subsequent tests, KRW characterized the performance of the zinc ferrite system using ceramic candle filters upstream of the sorbent vessel. The particle loading to the zinc ferrite bed was less than 5 ppmw during these tests. These tests were conducted with a $0.61-\mathrm{m}(2-\mathrm{ft})$ diameter by $2.24-\mathrm{m}(7.35-\mathrm{ft})$ high desulfurization reactor containing $862 \mathrm{~kg}(1,900 \mathrm{lb})$ of zinc ferrite. At an inlet $\mathrm{H}_{2} \mathrm{~s}$ concentration of $1,000 \mathrm{ppmv}$, the outlet $\mathrm{H}_{2} \mathrm{~S}$ concentration was consistently less than 20 ppmv before sulfur breakthrough. The tests demonstrated that good operability and a very low level of $\mathrm{H}_{2} \mathrm{~S}$ in the product fuel gas is readily achievable, with efficient particle control prior to the packedbed of zinc ferrite.

Ceramic Candle Hiltex. A 33-element, ceramic candle filter system was tested at the KRW fluidized-bed gasification facility (Bossart 1989; Bossart and Nakaishi 1990). An advanced particle control technology is needed upstream to prevent plugging of the packed-bed desulfurization reactor and possible reaction of the desulfurization sorbent (e.g., zinc ferrite) with carbonaceous coal fines. An advanced particle control technology could be needed downstream to collect fines generated from degradation of the desulfurization sorbent. Both $1-\mathrm{m}(3.3-\mathrm{ft})$ long and $1.5-\mathrm{m}$ (4.9-ft) long candle filter elements were tested at KRW. The candle filter system was tested upstream of the desulfurization reactor in two tests and downstream in the following three test.s.

The test series involved 13 startup-shutdown cycles, 653 hours of exposure to coal gas, and 2,253 pulse cleaning 
cycles. Nominal test conditions were temperatures of 427 to $621^{\circ} \mathrm{C}$ ( 800 to $1,150^{\circ} \mathrm{F}$ ), pressures of 1.0 to $1.69 \mathrm{MPa}$ (145 to $245 \mathrm{psia}$, filtration velocities of 0.0076 to $0.026 \mathrm{~m} / \mathrm{s}$ (1.5 to $5.2 \mathrm{ft} / \mathrm{min})$, and inlet particle loadings between 200 and 1,000 ppmw.

The candle filter system demonstrated the capability of meeting NSPS for particle emissions and particle tolerance limits for gas turbines with typical particle loadings at the outlet of the ceramic candle filter system of 1 to 5 ppmw. These candle filters are being analyzed by Acurex Lorporation to determine if exposure to the gasification environment had any detrimental effects on the strength and filtration capabilities of the material.

\section{Texaco Entrained-Bed}

Hot gas cleanup activities at the Texaco entrained-bed gasification facility in Montebello, California, included investigation of in-situ desulfurization, external desulfurization, and advanced particle control with a ceramic cross-flow filter system (Robin, Wu, and Kassman 1990).

In-situ Desulfurization. In-situ desulfurization was accomplished by adding sulfur sorbent to the coal-water slurry. The addition of iron oxide to the coal-water slurry rosulted in a nominal 50 percent reduction of $\mathrm{H}_{2} \mathrm{~S}$ in the coal-gas. The addition of ixon oxide and sodium carbonate to the coal-water slurry resulted in a 60 pexcent reduction of $\mathrm{H}_{2} \mathrm{~S}$ in the coal-gas. However, further investigation of adding sodium carbonate to the coal-water slurry was terminated because of its detrimental efrect on the slag stability. Additional in situ desulfurization tests are planned with limestone and dolomite additions to the coal-water slurry.

External Desulfurization. The sulfidation performance of four external sorbents was evaluated in packed-bed desulfurization reactors using a slipstream of coal-gas with an $\mathrm{H}_{2} \mathrm{~s}$ content between 1, 600 and $14,500 \mathrm{ppmv}$. The four regenerable, desulfurization sorbents included two zinc ferrite formulations, a coppercontaining zine ferrite soxbent, and a zinc oxide-titanium oxide sorbent. All of the sorbents were able to remove greater than 99.9 percent of $\mathrm{H}_{2} \mathrm{~S}$ from the coal-gas prior to breakthrough of sulfur. In oxygen-blown tests, the iron oxide-containing sorbents were found to be unsuitable for use in the Texaco entrained-bed gasification process due to a severe loss of strength and their catalytic effect on the methanation reaction. Future tests with external desulfurjzation sorbents will emphasize zinc oxide-titanium oxide formulations. 
Ceramic Cross-Flow Filter. The performance of a fourelement, ceramic cross-flow filter system was tested for 228 hours at the Texaco pilot-plant, entrained-bed gasification facility in Montebello, California. The nominal operating conditions were a temperature of $732^{\circ} \mathrm{C}\left(1,350^{\circ} \mathrm{F}\right)$, a pressure of $2.51 \mathrm{MPa}$ ( $365 \mathrm{psia}$ ), a maximum gas flowrate of $47.2 \mathrm{I} / \mathrm{s}$ (100 actual cubic feet per minute $\left.\left[\mathrm{ft}^{3} / \mathrm{min}\right]\right)$, and a particle loading ranging from 2,000 to 22,000 ppmw. One important finding was that the fine char/ash produced by the gasifier caused a higher-than-expected pressure drop across the cross-flow filter system. Additional testing is planned at Texaco using eight elements to reduce the pressure drop across the cross-flow filter system.

To complement the tests in Montebello, two ceramic crossflow filters will be tested for over 2,000 hours under simulated Texaco gasification conditions at the Westinghouse Science and Technology Center. Nominal operating conditions for this test will be a temperature of $649^{\circ} \mathrm{C}\left(1,200^{\circ} \mathrm{F}\right)$, a pressure of $0.58 \mathrm{MPa}$ (85 psia), a face velocity of $0.015 \mathrm{~m} / \mathrm{s}$ (3 ft/min), and a particle loading of 1,000 ppmw. Over 450 hours have been completed, which included 88 cleaning cycles and 7 startups and shutdowns. The outlet particle loading has avexaged less than 3 ppmw.

\section{GR Fixed-Bed Gasifier}

The GE fixed-bed gasifier system may only require cyclons separators for adequate particle control to protect the gas turbine, but a hot gas desulfurization system will be needed to meet NSPS for $\mathrm{SO}_{2}$ emissions. GE Environmental Services, Inc., plans to demonstrate the operation of a noving-bed, hot gas desulfurization system integrated with the GE subpilot-scale, fixed-bed coal gasifier in Schenectady, New York. The process configuration for the gasifier and the moving-bed, hot gas desulfurization system is shown in Figure 12 (Smith 1988).

The demonstration tests will be operated at a temperature of 566 to $621^{\circ} \mathrm{C}\left(1,050\right.$ to $\left.1,150^{\circ} \mathrm{F}\right)$ and a pressure of $2.18 \mathrm{MPa}$ (315 psia). An advanced formulation of zinc ferrite, which has been developed to preserve chemical reactivity while improving mechanical durability, will be evaluated in the moving-bed reactor system (Ayala et al. 1990). Initial testing showed that the moving-bed zinc ferrite system was able to remove sulfur to levels less than $10 \mathrm{ppmv}$ in the temperature range of 443 to $.593^{\circ} \mathrm{C}$ $\left(830\right.$ to $\left.1,100^{\circ} \mathrm{F}\right)$. The sorbent was easily regenerated and sorbent attrition was acceptable (i.e., less than 0.5 percent sorbent attrition to less than 20 mesh). 


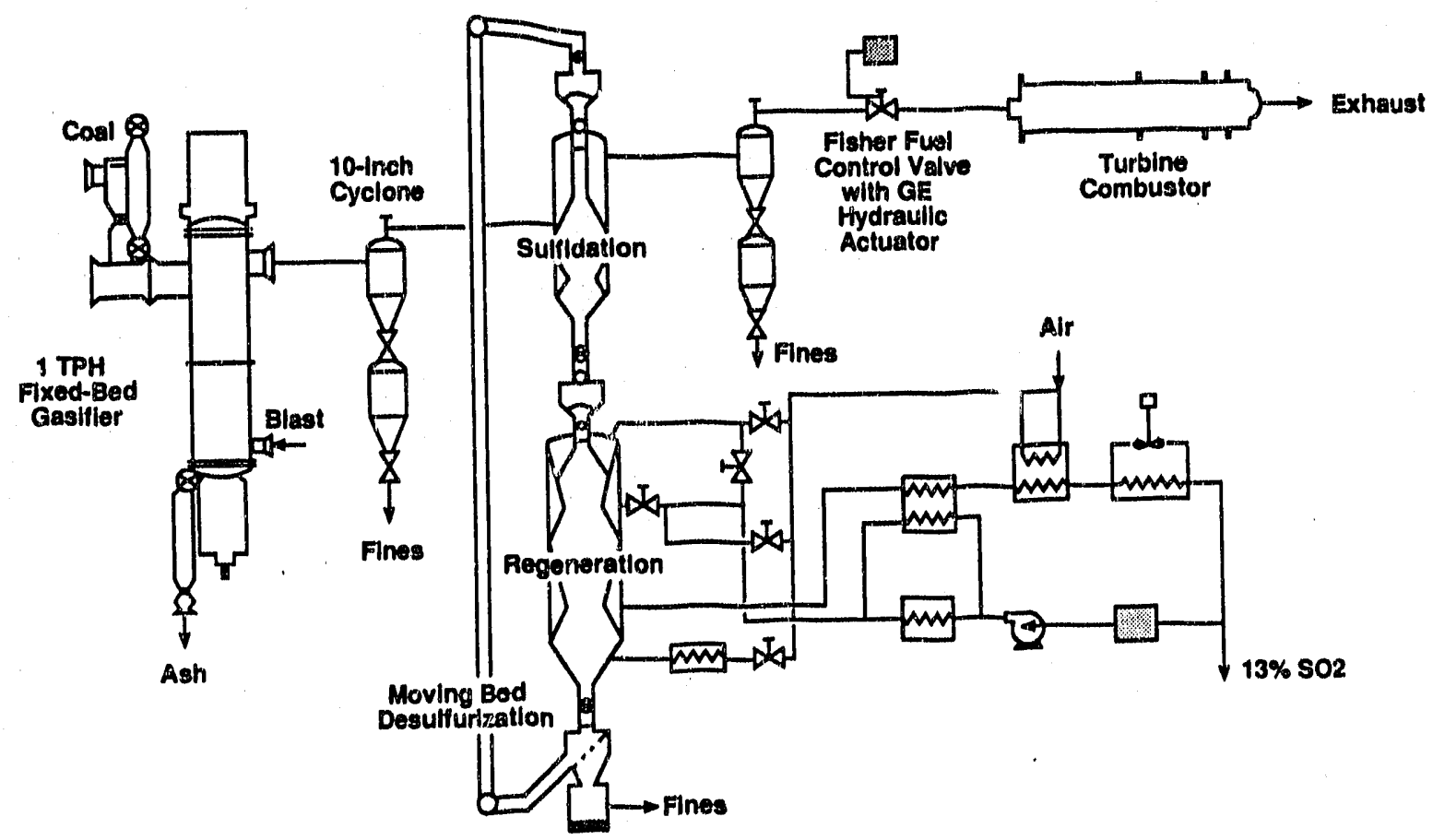

M91001332

Higure 12. GE Gasilier and Moving-Bad, Hot Gas Desulfurization system

The moving-bed, hot gas desulfurization system has several significant advantages over the conventional, packed-bed desulfurization system. These advantages include decrease in sulfate formation during regeneration, ease of temperature control during regeneration, reduction in accumulated coal fines during sulfidation, utilization of full sulfur capacity of sorbent, operation at steady-state conditions, and potential for production of regeneration offgas with a high $\mathrm{SO}_{2}$ concentration for sulfuric acid production.

\section{Calderon Proctas:}

Elemental sulfur production is another viable option for fixation of sulfur in coal-derived gases from IGCC processes. The Calderon gasification/hot gas cleanup process (Figure 13) is targeted to electric power generation with co-production of methanol and by-product elemental sulfur. The "rich gas" generated by the pyrolyzer is contacted with lime in a rich gas contactor for removal of sulfur and cracking of hydrocarbons to carbon, carbon monoxide, and hydrogen. The carbon monoxide and 


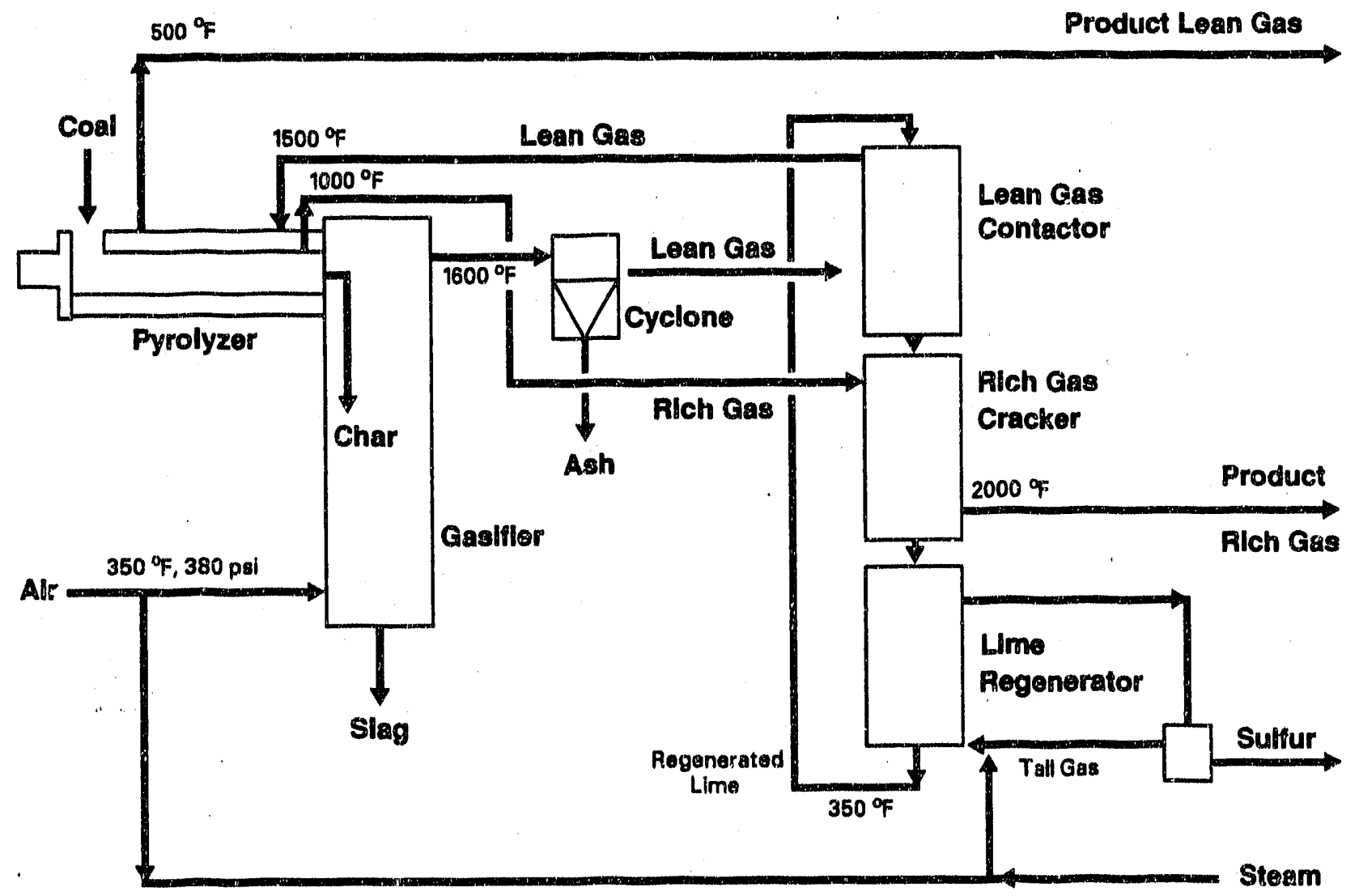

M91000582

\section{Eigure 13. Calderon Process Dovelopment Unit}

hydrogen mixture is suitable for production of methanol. The char from the pyrolyzer is gasified with air to produce a "lean gas." particles in the "lean gas" are removed by a hot cyclone located upstream of a movingmbed reactor of lime that removes sulfur compounds. The lime sorbent is regenerated with air to recover elemental sulfur as a by-product. The cleaned "lean gas" is combusted in a gas tuxbine to produce electricity.

Construction of a Provess Development Unit (PDU) for demonstrating the Calderon gasification/hot gas cleanup process was completed in June 1990. The RDU will be operated for a minimum of 6 months with a maximum feed rate of minimally cleaned, high sulfur coal of 1 ton per hour. Results from the PDU test program will be used to develop a commercial-scale design and cost analysis for a 48-MWe power plant based on the Calderon gasification/ hot gas cleanup process. 


\section{Southorn Company Services}

A 5-year joint DOE/industry project was initiated in 1990 to evaluate advanced particle control technologies in an integrated coal-fired test facility. SCs will manage the project with the participation of M. W. Kellogg (MWK), Southern Research Institute, Al dbama Power Company, and Southern Electric International as major subcontractors. The test facility will be located at an existing SCS power plant near Wilsonville, Alabama. The test facility will include a transport reactor developed by MWK, which is capable of operating as a circulating fluidized-bed combustor or a gasifier.

The purpose of this project is to evaluate the technical feasibility of incorporating advanced particle control technologies in IGCC and PFEC systems at a scale between bench-scale and commercial demonstration. The coal feed rate to the transport reactor is $1,814 \mathrm{~kg} / \mathrm{h}$ (2 tons $/ \mathrm{h}$ ), which produces up to $944 \mathrm{I} / \mathrm{s}$ $\left(2,000\right.$ actual $\left.\mathrm{ft}^{3} / \mathrm{min}\right)$ of coal-derived gas for evaluation of advanced particle control technologies. This flowrate is suitable for demonstrating the technical feasibility of integrating advanced particle control technologies into IGCC and PFBC systems. Advanced particle control technologies being considered for testing at wilsonville include the ceramic candle filter, ceramic tube filter, ceramic cross-flow filter, moving granular bed filter, acoustic agglomeration, and nested fiber filter. Construction of the facility is expected to be completed in early 1993, followed by testing of two particle control technologies by 1995.

\section{Other GSCU Projects for IGCC}

Novel Desulfuriration sorbents. Operating limitations of the zinc ferrice desulfurization sorbent has led to development of novel sorbents that offer advantages over the zinc ferrite sorbent in certain applications. These advantages include extension of the operating temperature above $677^{\circ} \mathrm{C}\left(1,250^{\circ} \mathrm{F}\right)$, removal of sulfur to less than 1 ppmv, simplified handling of regeneration offgases, increased sorbent capacity, and capability to mitigate other coal-derived contaminants (e.g., ammonia and chloride).

Five novel sorbents that offer improvements over zinc ferrite have been studied by Research Triangle Institute (RTI) in a bench-scale reactor using simulated fuel gas (Gangwal et al., Multicycle Testing, 1988; Bench-Scale Testing, 1988; Bench-Scale Testing, 1989; Testing of Novel Sorbents, 1989; Gangwal, Harkins, and Jain 1990). The novel sorbent formulations included a copper-containing zinc ferrite, zinc titanate, copper aluminate, copper ferrite aluminate, and copper manganese oxide. 
Promising results were obtained with the zinc copper ferrite and zinc titanate sorbents. The copper-containing zinc ferrite formulation was able to reduce sulfur levels to less than 1 ppmv prior to sulfur breakthrough at about 15 percent average sulfur capacity in the sorbent. This sulfur concentration is much lower than required to meet NSPS for $\mathrm{SO}_{2}$ emigsions and may be suitable for reliable operation of a MCFC.

The zinc titanate formulation has the potential to extend the operating temperature range of zinc-based sorbents to about $760^{\circ} \mathrm{C}\left(1,400^{\circ} \mathrm{g}\right)$. It also lessens the concern for carbide formation and carbon deposition in highly reducing gas streams. Zinc titanate operated with fuel gas from entrained-bed gasifiers at conditions where the use of zinc ferrite would be impractical; zinc ferrite at these conditions would require the addition of significant quantities of steam to lessen the "reducing" potential of the fuel gas.

Most tests of mixed-metal oxide sorbents have been conducted in packed-bed reactors, and proof-of-concept tests are beginning with the moving-bed system at GE. RTI has recently initiated desulfurization tests using fluidized-bed reactors containing the zinc ferrite sorbent. RTI completed a 100-cycle test in a $51-\mathrm{mm}$ (2-in) diameter fluidized-bed reactor. This test showed that the $\mathrm{H}_{2} \mathrm{~S}$ in the simulated coal gas could be consistently reduced to less than 20 ppmv. METC has also initiated tests using mixedmetal oxides supported on zeolites. The advantages of supported sorbents include superior crush strength, attrition resistance, and ability to withstand temperatures as high as $927^{\circ} \mathrm{C}\left(1,700^{\circ} \mathrm{F}\right)$. The expected advantages of fluidized-bed reactors include better temperature control of exothermic reactions, excellent gas-solid contacting, prevention of solids segregation, greater flexibility in sorbent regeneration, elimination of valves, and continuous steady-state operation.

DSRP. Sulfur dioxide produced during regeneration of the mixed-metal oxides must be fixed in some manner (Woodland 1988). Optioss include injection of the regeneration offgas into the gasifier for removal of $\mathrm{SO}_{2}$ by the in-bed desulfurization sorbent, removal of $\mathrm{SO}_{2}$ by contact with an external bed of lime or limestone, and production of elemental sulfux or sulfuric acid. One novel concept for producing elemental sulfur is the direct. sulfur recovery process (DSRP) being developed by RTI (Dorchak, Gangwal, and Harkins 1988; Dorchak and Gangwal 1990; Dorchak, Gangwal, and McMichael 1990; Gangwal, Harkins, and Woods 1988). DSRP uses a sodium-alumina catalyst to convert $\mathrm{SO}_{2}$ directly to elemental sulfur under HTHP conditions. In laboratory-scale studies, over 95 percent of the $\mathrm{SO}_{2}$ was converted to elemental sulfur in a single-stage process, while over 99.5 percent conversion to elemental sulfur is expected in a two-stage process. 
WO Fraisaions. Processes for control of NO emissions will likely be required in most IGCC system configurations (Williams and Kothari 1989). Catalytic decomposition of ammonia and staged combustion are leading contenders for $\mathrm{NO}_{\mathrm{x}}$ control strategies in IGCC systems. Acurex Corporation has demonstrated the effectiveness of staged combustion for control of $\mathrm{NO}_{\text {, emissions from gas }}$ turbines using simulated hot fuel gas in the range of 538 to $871^{\circ} \mathrm{C}\left(1,000\right.$ to $\left.1,600^{\circ} \mathrm{F}\right)$. They were able to achieve over 95 percent conversion of ammonia to $\mathrm{N}_{2}$. The $\mathrm{NO}_{x}$ concentration in the exhaust gas was 50 ppinv when over 95 percent of 5,000 ppinv ammonia in the simulated fuel gas was converted to $\mathrm{N}_{2}$. This emission level Nill meet NSPS for NO emissions. Further reduction of NO levels down to 14 ppmv was achieved using an ammonia decomposition catalyst following the primaxy combustion stage. While the results are encouraging, the use of staged combustion would require significant combustor modifications to accommodate the relatively long residence times required to minimize $\mathrm{NO}_{x}$ emissions.

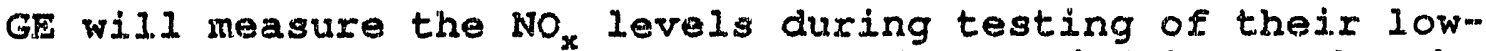
Btu fuel gas combustor. The low-Btu fuel gas will be produced from the GE fixed-bed gasifier. Prior to combustion, particles are removed from the fuel gas in a cyclone separator and gaseous sulfur compounds are removed in a moving-bed zinc ferrite system. Exhaust gases from the combustor will flow through a gas turbine simulator.

Ammonia. SRI International tested several catalysts for their ability to decompose ammonia using simulated coal gas containing 5,000 ppmv ammonia (Krishnan 1988). A nickel-based catalyst was able to decompose 90 percent of the ammonia at $788^{\circ} \mathrm{C}$ $\left(1,450^{\circ} \mathrm{F}\right)$ and not be poisoned by the presence of $3,000 \mathrm{ppmv} \mathrm{H}_{2} \mathrm{~S}$. other catalysts were able to decompose ammonia effectively at lower temperatures, but were rapidly poisoned by sulfur. Thus, while catalysts have been identified for operation at $788^{\circ} \mathrm{C}$, sulfur-tolerant catalysts are not yet available for operation at the lower temperatures and higher ammonia levels that are characteristic of the fuel gas from fixed-bed gasifiers. Additional concerns with these catalysts are possible deactivation by other trace contaminants, such as chlorides, tars, and trace metals.

Tex. For IGCC systems based on fixed-bed gasifiers, tar removal may be nevessary to minimize equipment fouling and to meet environmental regulations for $\mathrm{NO}_{x}$ and $\mathrm{SO}_{2}$ emissions.

Battelle Pacific Northwest Laboratories conducted a screening study to develop a catalyst system for cracking tars in fuel gases upstream of a regenerable, mixed-metal oxide desulfurization process. The objective was to convert the sulfur in tars to $\mathrm{H}_{2} \mathrm{~S}$ for removal by the hot gas desulfurization process. Acid 
cracking catalysts (such as low-sodium, type y zeolite) and hydrocracking catalysts based on $Y$ zeolite were found to be the most effective catalysts, since they cracked about 90 percent of the tars. In this catalyst sysiem, the converted tars are distributed to the char (50 percent), gases (39 percent), and light oils (11 percent). Sulfur in the converted tars is distributed between gases ( 76 percent) and char (24 percent). The catalyst requires frequent regeneration with steam and air to maintain activity.

\subsubsection{Assessment}

Fixed-bed, fluidized-bed, and entrained-bed gasifiers in IGCC systems operate under different conditions and produce fuel gases with varying types and quantities of contaminants. Promising results have been obtained in pilot-scale test programs using calcium-based soxbents for in-bed desulfurization in a fluidizedbed gasifiex, external desulfurization with a packed-bed of zinc ferrite, and ceramic cross-flow and candle filters for control of particles. Promising results have also been obtained in benchscale programs for control of tars and ammonia. Catalytic decomposition of ammonia and staged combustion are being investigated for $\mathrm{NO}_{x}$ control.

Some remaining technical issues include durability of advanced particle filters and mixed-metal oxide sorbents; development of methods for treatment of sulfur in regeneration offgas; and optimal reactor configuration for mixed-metal oxide desulfurization processes. Each of these issues is currently being. addressed in the GSCU and Gasification Programs.

\section{Gas Stream Cleanup for Gasification/Eual Col1 Systems}

\section{4.1 status}

Gas stream cleanup requirements for gasification/MCFC and gasification/SOFC systems are more stringent than those for gas turbine applications. The contaminants of major concern in gasification/fuel cell systems are sulfur and nitrogen compounds, particles, alkali compounds, and trace contaminants such as chlorides, zinc, mercury, lead, and arsenic.

Rreliminary contaminant tolerance limits for the MCFC system are summarized in Table 5 (Magee et al. 1987; Pigeaud and Klinger 1987; Remick, Tewulski, and Lu 1987). These contaminant tolerance limits are based on experiments in which the MCFC was expcsed to a single contaminant in a simulated gas. The possible synergistic effects of these contaminants on MCFC performance are being examined by Energy Research Corporation. Table 5 also 
Tablo 5. Molten Carbonate Fuel Cell Contaminanta and Tolerance Iimits

\begin{tabular}{|c|c|c|}
\hline Contaminane & $\begin{array}{c}\text { Individual } \\
\text { Tolerance } \\
\text { Iimit } \\
\end{array}$ & $\begin{array}{c}\text { Typical Uncontrolled } \\
\text { Fuel Gas } \\
\text { Concentration }\end{array}$ \\
\hline $\mathrm{H}_{2} \mathrm{~S}$ & 1 ppmv & $1.5 \mathrm{vol} \&$ \\
\hline $\mathrm{H}_{2} \mathrm{Se}$ & 1 ppmv & 5 ppmv \\
\hline $\mathrm{zn}$ & 5 ppmv & 100 ppmv \\
\hline $\mathrm{cd}$ & $30 \mathrm{ppmv}$ & 5 ppmv \\
\hline $\mathrm{NH}_{3}$ & 1 vol \& & $1.5 \mathrm{rol} \&$ \\
\hline As & 1 ppmv & $10 \mathrm{ppmv}$ \\
\hline $\mathrm{HCl}, \mathrm{HF}^{1}$ & 0.1 ppmv & $\begin{array}{l}500 \text { ppmv (HCI) } \\
200 \text { ppmv (HF) }\end{array}$ \\
\hline $\mathrm{Hg}$ & (2) & 0.5 ppmv \\
\hline $\mathrm{Pb}$ & (2) & 15 ppmv \\
\hline $\begin{array}{l}\text { Hydrocarbons } \\
\text { Satuxated } \\
\text { olefins } \\
\text { Aromatic } \\
\text { Cyclic }\end{array}$ & $\begin{array}{lll}12 & \text { vol } \\
0.2 & \text { vol } & 8 \\
0.5 & \text { vol } & 8 \\
0.5 & \text { vol }\end{array}$ & \\
\hline $\begin{array}{l}\text { Alkali (Na, K) } \\
\text { Particles }\end{array}$ & $\begin{array}{l}\text { (2) } \\
10 \mathrm{ppmw}\end{array}$ & $\begin{array}{l}0.05 \text { to } 1.0 \text { ppmw } \\
3,000 \text { ppmw }\end{array}$ \\
\hline
\end{tabular}

2 Hydrogen Eluoride.

2 To Be Determined.

shows the expected, uncontrolled levels for each of the contaminants in the fuel gas, indicating that highly efficient contaminant removal systems may be necessary. The Westinghouse science and Technology Center is beginning to isvestigate the effects of particles, alkali compounds, sulfur compounds, chlorides, heavy metals, hydrocarbons, and other contaminants on SOFC performance.

Particle Control. Testing of the ceramic cross-flow filter, ceramic candle filter, screenless granular bed filter, nested fiber filter, and acoustic agglomeration under gasification and/or PEBC conditions indicates that these advanced particle control devices are capable of meeting particle tolerance limits 
for fuel cells. Particle loading at the outlet of these devices is consistently less than $10 \mathrm{ppmw}$, and the particle size is primarily less than $10 \mu \mathrm{m}$. However, little information is available concerning the effect of fine particles (less than $1 \mu \mathrm{m}$ ) on fuel cell performance. The fuel cell may also be affected by trace species (e.g., alkali, cadmium, zinc, selenium, lead, and tin) that can condense on the particulate matter or that are constituents of the particulate.

Chloride Control. HCl can cause electrolyte loss in the MCFC by reacting with the electrolyte to form lower boiling point compounds (e.g., KCl, NaCl) which subsequently evaporate. SRI International evaluated several natural minerals and commercial sorbents for theix ability to remove HCl in MCFC applications. Three sodium carbonate-based minerals were selected for this study: shortite $\left(\mathrm{Na}_{2} \mathrm{CO}_{3} \cdot 2 \mathrm{CaCO}_{3}\right)$, nahcolite $\left(\mathrm{NaHCO}_{3}\right)$, and dawsonite ( $\mathrm{NaAl}(\mathrm{OH})_{2} \mathrm{CO}_{3}$ ). A commercial chloride removal sorbent, Katalco Chloride Guard 59-3, was selected as a referenco material. In laboratory tests, all sorbents were able to reduce $\mathrm{HCl}$ from $300 \mathrm{ppmv}$ to about 1 ppmv at temperatures of 538 to $649^{\circ} \mathrm{C}$ $\left(1,000\right.$ to $\left.1,200^{\circ} \mathrm{F}\right)$. The calcined nahcolite exhibited the nighest chloride capacity of all sorbents by adsorbing chloride to 54 percent of its total weight.

A bench-scale study conducted with simulated coal gas containing $\mathrm{H}_{2} \mathrm{~S}$, hydrocarbon, and trace metal impurities confirmed the results of the laboratory studies. The presence of $\mathrm{H}_{2} \mathrm{~S}$ and trace metal impurities in the coal gas did not significantly affect the performance of the chloride removal sorbents, but the presence of hydrocarbons appeared to decrease the rate of chloride retention by the sorbents. Nahcolite was identified as the best sorbent because of its high chloride capacity and moderate cost. A commercial-scale chloride control system was designed based on installation in a 100-MWe MCFC power plant. The cost of the chloride control process using calcined nahcolite was $\$ 0.0017 / \mathrm{kWh}$ for the Texaco-based gasifier system and $\$ 0.0031 / \mathrm{kWh}$ for the Lurgi-based gasifier system.

IGT investigated sorbents containing molten carbonate to remove HCl at high temperature (Anderson et al. 1988). It was demonstrated in laboratory-scale tests that numerous, magnesiasupported, molten salt sorbents can reduce the HCl content to less than 1 ppmv. The sorbents were prepared with various formulations of sodium, lithium, potassium, and barium carbonates. The most reactive sorbent (50 percent $\mathrm{Na}_{2} \mathrm{CO}_{3} / 50$ percent $\mathrm{Li}_{2} \mathrm{CO}_{3}$ ) was able to reduce the $\mathrm{HCl}$ content from 300 ppmv to less than $0.1 \mathrm{ppmr}$ at $649^{\circ} \mathrm{C}\left(1,200^{\circ} \mathrm{F}\right)$ and atmospheric pressure conditions. The residual $\mathrm{HCl}$ concentration is over an order of magnitude lower than is achievable with nahcolite, but the cost of the molten salt process is three times higher than a process using solid nahcolite sorbent. 
sulfur Control. The sulfur tolerance limits for MCFC applications is less than 1 ppmv (Table 5). Several of the novel mixed-metal oxide desulfurization sorbents being developed for gas turbine applications may also be able to meet the more stringent sulfur tolerance limits of the MCFC. In particular, the copper-containing zinc ferrite sorbent is able to reduce sulfur levels to less than 1 ppmv.

Trace Contaminants. Trace contaminants that can block or deactivate the anode in MCFC systems include selenium, zinc, cadmium, arsenic, mercury, tin, and lead. Energy Research Corporation is performing experiments to develop MCFC tolerance specifications for these contaminants along with major contaminants, including particulates, sulfur compounds, halogenated. compounds, hydrocarbons, and ammonia.

There is a limited data base for measurements of trace contaminant levels in coal-derived gas streams. The data base is limited because reliable and accurate techniques for sampling and analyzing trace contaminants in the HTHP gas streams of coal gasification processes aro unavailable. Most past measurements of trace contaminant levels in the gas streams of coal gasification processes involved absorption of the contaminant into solutions of varying $\mathrm{pH}$ content. This method requires long sampling periods to collect a sufficient quantity of contaminant for analysis by atomic absorption spectroscopy. The results represent time-averaged concentrations over the sampling period rather than discrete concentrations. Major concerns regarding the absorption method include uncertainties in contaminant collection efficiency, contamination in the sample conditioning system, and inability to differentiate the contaminant concentration in the vapor phase from the contaminant concentration leached from particulates in the gas stream. On-line methods being developed to analyze trace contaminants in gas streams are based on atomic absorption spectroscopy, atomic emission spectroscopy, and inductively coupled plasma spectroscopy.

\subsubsection{Assaesment}

The hot gas cleanup requirements for gasification/MCFC and gasification/SOFC systems are not completely defined since no tests have been performed with integrated gasification/fuel cell systems. Preliminary contaminant tolerance limits for particles, sulfur, chloride, and several trace metals have been defined for MCF'C systems. The tolerance limits were based on MCEC exposure tests with a single contaminant in a simulated coal gas. The effects of combining contaminants in an actual coal gas are unknown. The hot gas cleanup requirements for MCFC are more stringent than cleanup requirements for gas turbine systems (i.e., IGCC, DCET, and EFBC) and represent a greater challenge 
for development of hot gas cleanup technologies. However, many of the contaminant control technologies being developed for gas turbine systems can be applied to MCFC and sOFC systems.

\subsection{Gas stream Cleanup for Coal-Fueled Diesel Systems}

\subsubsection{Status}

Gas stream cleanup for CED systems has focused on control. of particulates, $\mathrm{SO}_{2}$, and $\mathrm{NO}_{x}$ in the diesel exhaust gas both upstream and downstream of the turbocharger (Figure 5) (Carpenter et al. 1988). Contaminant control strategies are different for each location since the temperature of the gas upstream of the turbocharger is 427 to $538^{\circ} \mathrm{C}\left(800\right.$ to $\left.1,000^{\circ} \mathrm{F}\right)$, while the downstream temperature is less than $177^{\circ} \mathrm{C}\left(350^{\circ} \mathrm{F}\right)$.

\section{Stationary CoaI-Wueled Dienel Syatem}

Cost study. Arthux D. Iittle (ADL) and its subcontractors, Cooper-Bessemer and PSI Technology (PSIT) Company, are developing a stationary CFD system capable of generating power at a competitive cost with low emissions. PSIT is responsible for developing a reliable, cost-effective emissior control system for a diesel engine fueled with a coal-water slurry. Capital and operating costs were estimated for several emission control systems that use combinations of commercial and non-commercial technologies for control of particulates, $\mathrm{SO}_{2}$, and $\mathrm{NO}_{x} \cdot$ Reasonably inexpensive technologies that have a high probability of technical success were emphasized. Nonetheless, the cost study indicates a need to develop less expensive technologies for NO $_{x}$ and $\mathrm{SO}_{2}$ reduction. The high cost of the commexcial technologies for $\mathrm{NO}_{x}$ control (e.g., selective catalytic reduction) and $\mathrm{SO}_{2}$ control (e.g., spray dryer) would hinder the coal-fueled diesel engine from competing economicaliy in the small (e.g., 10 MWe) power production market.

Particle Control. In the ADI diesel system, cyclones protect the turbocharger by removing particles larger than $5 \mu \mathrm{m}$ in the exhaust gas from the diesel engine. A baghouse is used downstream of the turbocharger and waste heat boiler to meet environmental regulations for particulate emissions.

$\mathrm{SO}_{2}$ Control: One method explored for $\mathrm{SO}_{2}$ control was injection of hydrated lime into the diesel exhaust gas upstream and downstream of the turbocharger. Injection of calcium hydroxide into the duct upstream of the turbocharger was very inefficient for $\mathrm{SO}_{2}$ removal and does not appear to be a suitable process for $\mathrm{SO}_{2}$ control in CFD systems. Injection of sorbent and water directly upstream of the baghouse resulted in about 70 percent 
reduction of $\mathrm{SO}_{2}$. However, a spray dryer will be needed if 90 percent reduction of $\mathrm{SO}_{2}$ is required to meet environmental regulations.

$\mathrm{NO}_{\mathrm{x}}$ Control. The three methods tested for $\mathrm{NO}_{\mathrm{x}}$ control were reburning, reduction with carbon-containing particulate matter, and selective non-catalytic reduction (SNR.). Reburning was found to be uneconomical because of the large amount of fuel required to reduce $\mathrm{NO}_{*}$.

The use of carbon-containing particulate matter in the gas as a reductant resulted in 50 to 70 percent $\mathrm{NO}_{x}$ reduction at temperatures greater than $260^{\circ} \mathrm{C}\left(500^{\circ} \mathrm{F}\right)$. These results suggest that particulate matter could be captured on a high-temperature filter and allowed to react with $\mathrm{NO}_{\mathrm{x}}$.

The SNR process uses a proprietary gas additive to reduce NO $x$ at temperatures between $399^{\circ}$ and $482^{\circ} \mathrm{C}\left(750\right.$ and $\left.900^{\circ} \mathrm{F}\right)$. In lab-scale experiments, over 90 percent No reduction was observed in the temperature range of $427^{\circ}$ to $449^{\circ} \mathrm{C}\left(800\right.$ to $\left.840^{\circ} \mathrm{F}\right)$. PSIT is currently evaluating these lab-scale results before selecting emission control technologies for testing in an integrated CFD system.

\section{Transportation Coal-Fueled Diesel System}

GE Transportation system is developing an emission control system for locomotives powered by CFD engines. The emission control system for coal-fired locomotives must consider cost and space limitations. A cyclone is installed upstream of the turbocharger to protect it from damage by large particles. A static granular bed filter and metallic candle filter were also investigated as particulate control devices. A granular bed filter containing copper oxide-coated alumina pellets removed 90 to 95 percent of the particles at face velocities between 0.15 and $0.61 \mathrm{~m} / \mathrm{s}$ ( 30 and $120 \mathrm{ft} / \mathrm{min})$. The GBF also removed greater than 90 percent of the $\mathrm{SO}_{2}$ and was shown to decompose hydrocarbons. The pressure drop across the GBE is expected to be acceptable for the duration of a typical locomotive trip at a face velocity of 0.15 to $0.31 \mathrm{~m} / \mathrm{s}(30$ to $60 \mathrm{ft} / \mathrm{min})$. The metal candle filters showed the potential for removing greater than 99 percent of the particulate. Pre-coating of the filter elements with coarse calcium-based sorbent will adsorb $\mathrm{SO}_{2}$ and lower the pressure drop across the filter. Addition of lime to the fuel resulted in only 25 percent reduction of $\mathrm{SO}_{2}$, while injection of dry hydrated lime and lime slurry into the exhaust gas resulted in 40 to 50 percent reduction in $\mathrm{SO}_{2}$ at a temperature of $399^{\circ} \mathrm{C}\left(750^{\circ} \mathrm{F}\right)$. 


\subsubsection{Assessment}

Several emission control technologies have demonstrated technical feasibility for successful application in CFD systems. The conditions in the diesel exhaust gas do not present as difficult a challenge for contaminant control as the severe ccnditions that exist in higher temperature (e.g., DCFT and PFBC) coal conversion systems. The uncertainty regarding possible environmental regulations for emissions from both stationary and transportation coal-fueled diesel systems complicates selection of control technologies. The choice of reliable, cost-effective emission control strategies is a key factor in determining the commercial potential for CFD systems in transportation and small power generation markets. It may be possible to control contaminants within the diesel engine, although no research is currently being conducted in this area.

\subsection{Gas Stream Cleanup for Mild Gasification Systems}

\subsubsection{Statuis}

The primary goal of the Mild Gasification Erogram is to investigate and develop gasification systems that can produce multiple, valuable products from coal. These multiple products are characterized as coal-derived liquids, gases, and chars that are generated through the application of advanced processing techniques, new catalysts, advanced treatment systems, and novel product upgrading techniques.

METC awarded four contracts in 1987 to examine novel MG processes. Contracts were awarded to Coal Technology Corporation (CTC), IGT, University of North Dakota Energy and Environmental Research Center (UNDEERC), and Western Research Institute (WRI). Cuxrently, these contractors are evaluating yields and properties of the gas, char, and liquid products generated by their processes. Technologies will be investigated for upgrading and removing contaminants from the multiple products. Removal of particulates, sulfur compounds, nitrogen compounds, chlorides, alkali compounds, and trace metals from the multiple products will probably be needed before the products are economical and envixonmentally safe. Fuel quality specifications will be determined for use of the products in heat engines, chemical manufacturing, and other applications.

\subsubsection{Assessment}

Developers of the MG processes are beginning to assess requirements for control of contaminants. Contaminant control for MG processes could be accomplished by several methods. For 
instance, contaminants could be removed by contaminant control subsystems; contaminant generation could be mitigated by changes in operating conditions; or contaminants could be removed from the end products through further processing. It is expected that removal of paxticulates, sulfur compounds, nitrogen compounds, chlorides, alkali compounds, and trace metals will be required to enhance the value of multiple products from MG processes. 


\subsection{SURPORTING GAS STREAM CLTEANUP RESIEARCH}

Research in several areas supports gas stream cleanup activities: membranes, instrumentation, and components.

\subsection{Mambranes}

In 1988, METC initiated a pingram to develop HTHP ceramic membranes for IGCC and DCET applici.tions (Cicero and Jarr 1989; Dellefield 1988; Jarr, Cicero, and Koch 1989). By operating at high temperature and pressure, membranes improve the economics of advanced power generation systems by reducing gas cleanup and separation cosțs. Two types of gas separation processes are being investigated (Figure 14): bulk separation of valuable products, such as $\mathrm{H}_{2}$; and selective removal of gaseous contaminants, such as $\mathrm{NH}_{3}, \mathrm{H}_{2} \mathrm{~S}, \mathrm{SO}_{2}$, and $\mathrm{NO}_{x}$. Typical membrane operating conditions are temperatures between $482^{\circ}$ and $1,232^{\circ} \mathrm{C} \quad\left(900^{\circ}\right.$ and $\left.2,250^{\circ} \mathrm{F}\right)$, and pressures between 1.0 and $6.9 \mathrm{MPa}$ (150 and 1,000 psia).

Membranes are classified according to the mechanism(s) used to separate the gas constituents. The types of membranes being developed include electrochemical, passive, facilitated transport, and catalytic. Research on electrochemical membranes for DCFT applications showed that $\mathrm{SO}_{2}$ and $\mathrm{NO}_{x}$ could be effectively removed, but the electrochemical membrane process was uneconomic due to substantial electrical requirements.

\section{Passive Mombrases}

ArCOA. ALCOA Separations Technology Division is evaluating their Membralox membrane, which is a tubular alumina with a 40-angstrom (A) pore diametex in the permselective layer (Figure 15). ALCOA completed a series of thermal stability tests, which demonstrated that the Membralox membrane is suitable for IGCC applications.

A high-temperature, leakproof seal system was developed for connecting the ceramic membrane tube to the stainless steel outer shell assembly. The material stability of the leakproof seal system under high temperature conditions proved to be poor. The membrane permselective layer exhibited delamination from the support layers at temperatures greater than $427^{\circ} \mathrm{C}\left(800^{\circ} \mathrm{F}\right)$ and with gas compositions containing water ( 10 vol percent). Because of these results, modifications to the membrane structure will be investigated to enhance gas separation performance and improve material stability. 


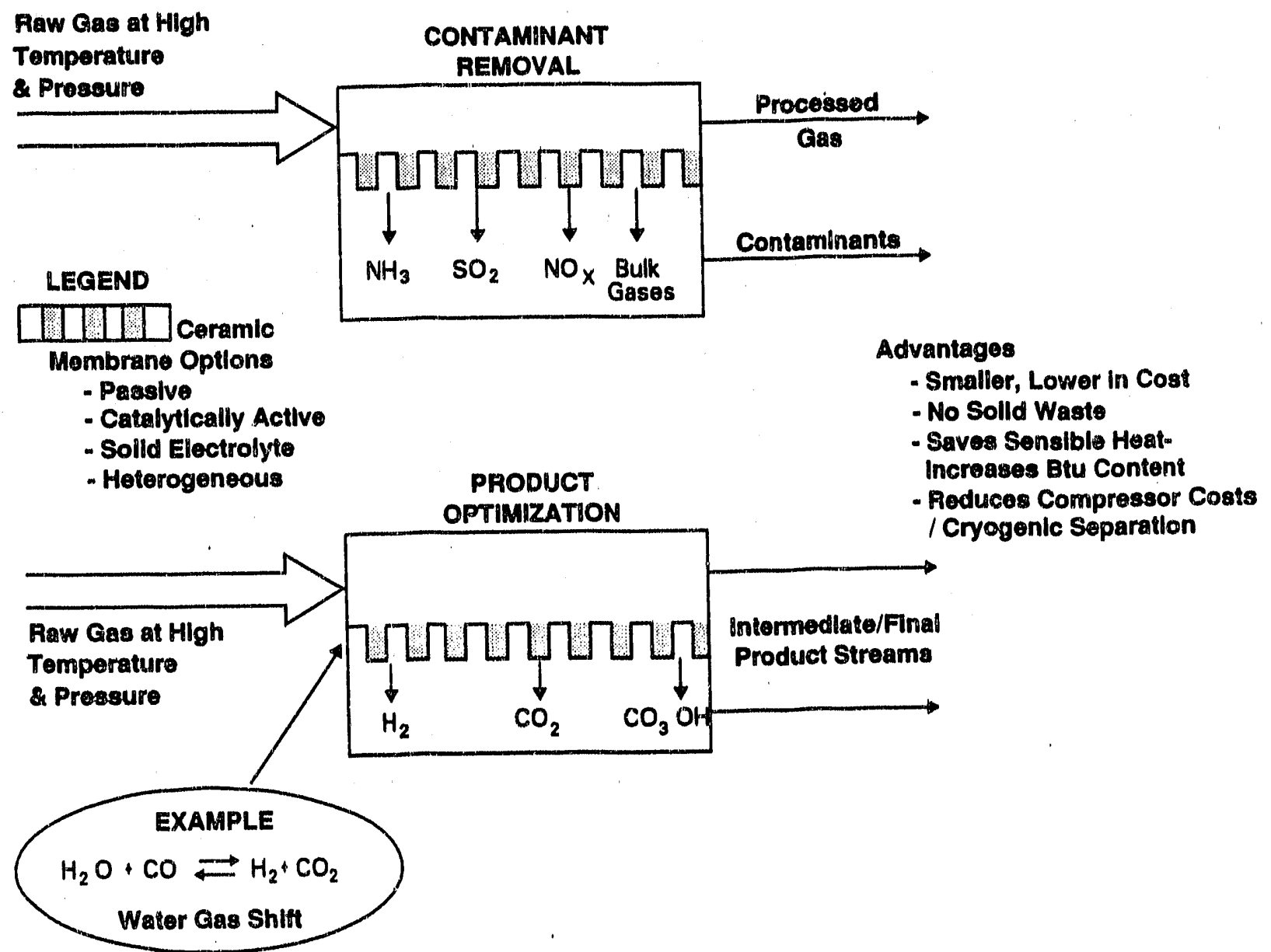

$M 91000583$

\section{Jigure 14. Mambran. Saparation of Gases}

SRI. SRI International is evaluating the silica hollowfiber membranes developed by Pittsburgh Plate and Glass (PPG) Industries. Data obtained at room temperature with the silica hollow fiber membrane indicated that gas permeability appears to be strongly relaced to molecular size rather than molecular weight. Additional tests are planned to determine gas permeability at temperatures up to $871^{\circ} \mathrm{C}\left(1,600^{\circ} \mathrm{F}\right)$ and pressures up to $3.5 \mathrm{MPa}$ (500 psia).

ORNL. ORNL is investigating gas separation in IGCC systems using ceramic materials technology developed for uranium enrichment. The objective of this project is to separate $\mathrm{H}_{2}$ and acid gases, such as $\mathrm{CO}_{2}$ and $\mathrm{H}_{2} \mathrm{~S}$, from synthesis gas. Significant improvements have been made in fabricating tubular alumina membranes at the Oak Ridge Gaseous Diffusion Plant. The average pore diameter was successfully reduced from about 300 A to 


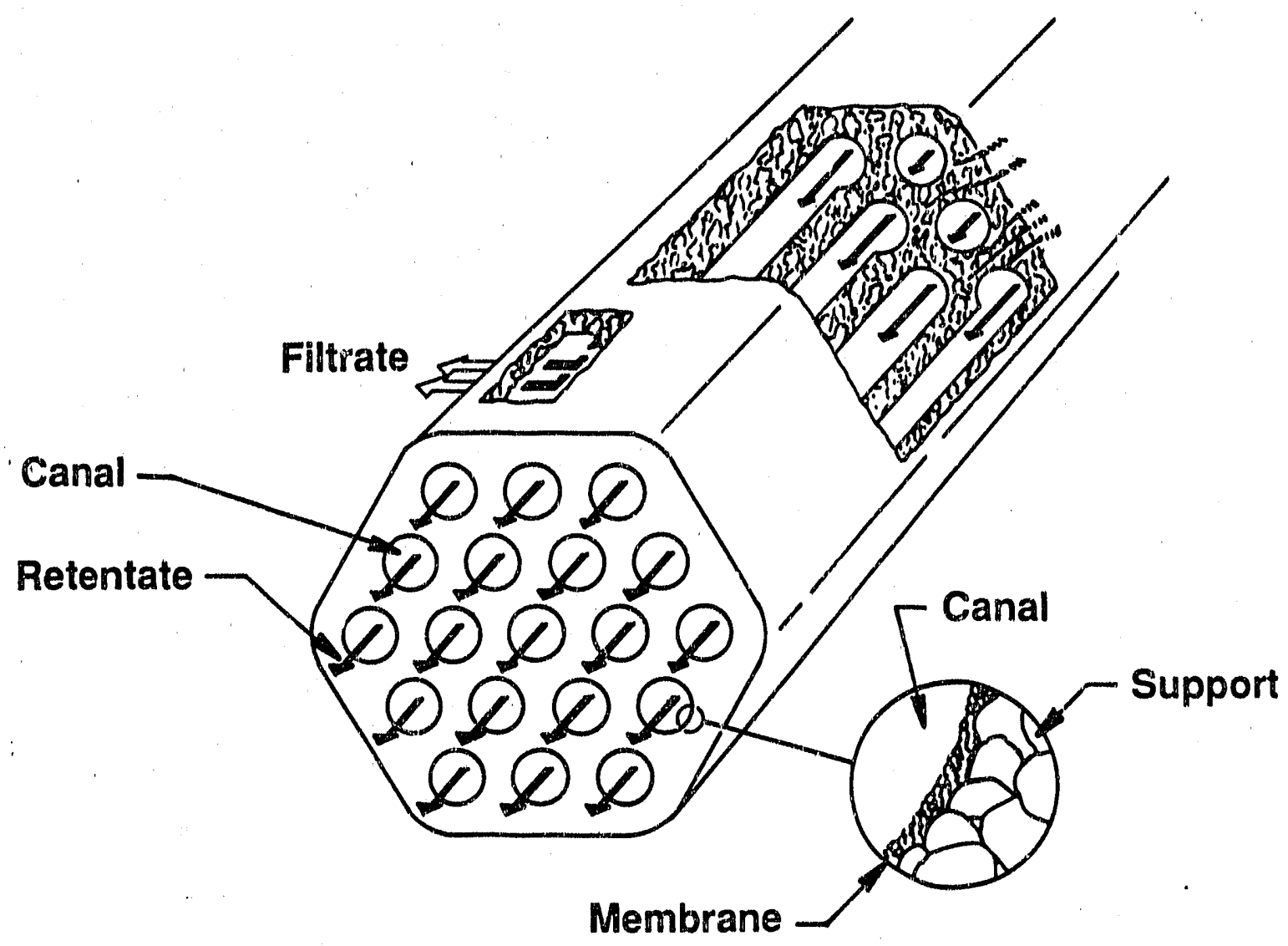

M91000584

\section{rigure 15. ALCOA Separation Technology Division' Membraloxo Mombrano}

approximately 15 to $40 \mathrm{~A}$. Membrane tests have been initiated at temperatures up to $449^{\circ} \mathrm{C}\left(840^{\circ} \mathrm{F}\right)$ and pressures up to $4.1 \mathrm{MPa}$ (600 psia). ORNI is actively pursuing declassification of theuranium enrichment technology and transfer of the membrane technology to industry.

\section{Hnhanced Mambranes}

Reactive ceramic membranes, which include facilitated transport and catalytic membranes, are being developad for contaminant control in IGCC systems. Facilitated transport membranes (Figure 16) are expected to exhibit improvements in selectivity and permeability compared to passive ceramic membranes. Molten alkali carbonate salts are used as the reactive compound incorporated into ceramic supports. Catalytic membranes (Figure 17) are expected to convert gaseous contaminants, such as $\mathrm{H}_{2} \mathrm{~S}$ and 


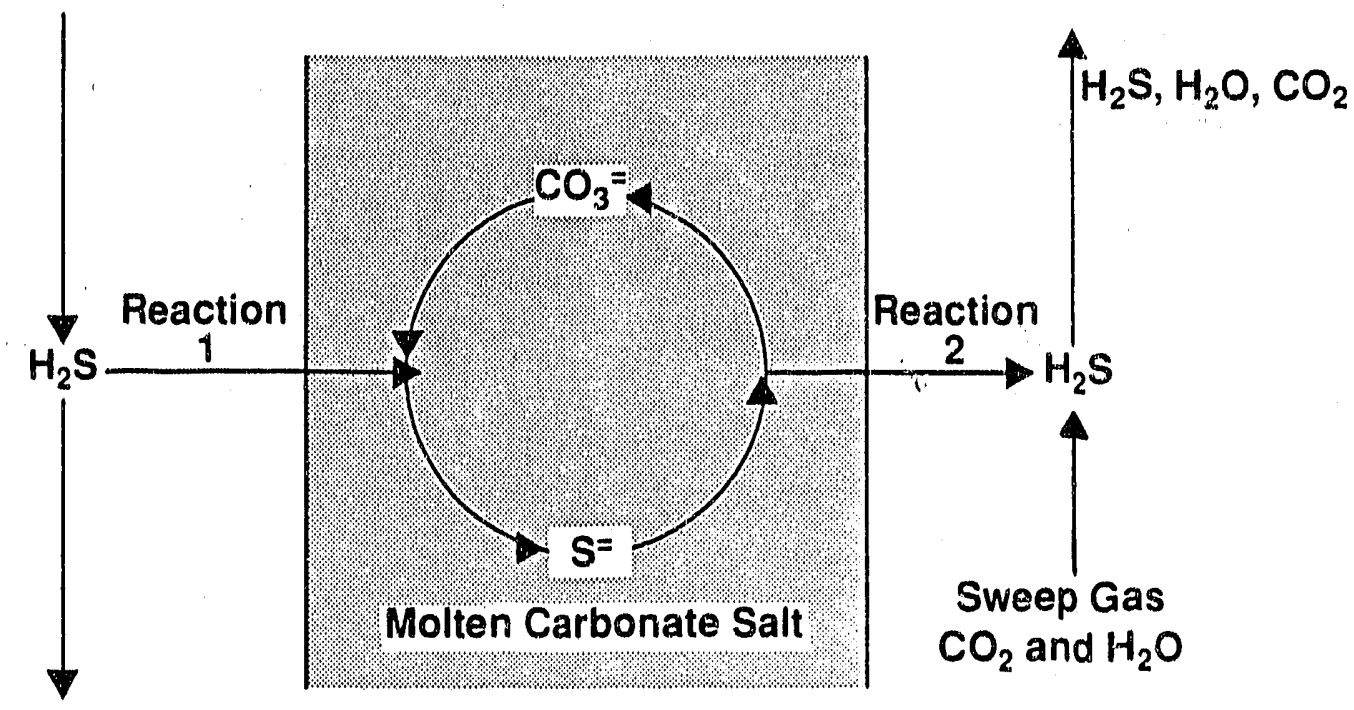

Reaction 1

Reaction 2

$\mathrm{H}_{2} \mathrm{~S}+\mathrm{CO}_{3}=\leftrightarrow \mathrm{S}=+\mathrm{H}_{2} \mathrm{O}+\mathrm{CO}_{2}$

$\mathrm{S}=+\mathrm{H}_{2} \mathrm{O}+\mathrm{CO}_{2} \leftrightarrow \mathrm{CO}_{3}=+\mathrm{H}_{2} \mathrm{~S}$

91000585

\section{Figux 16. Facilitated Transport Membrane}

$\mathrm{NH}_{3}$, to products that can be used in the process or selectively removed from the system.

WPI. Worcester Polytechnic Institute has begun research to develop catalyst-impregnated hollow fiber membrane reactors for the IGCC system. These catalytic reactors will simultaneously decompose $\mathrm{H}_{2} \mathrm{~S}$ and $\mathrm{NH}_{3}$ and separate the reaction products. The reactors will operate at temperatures ranging from 538 to $1,093^{\circ} \mathrm{C}$ $\left(1,000\right.$ to $\left.2,000^{\circ} \mathrm{F}\right)$ and pressures from 1.4 to $6.9 \mathrm{MFa}$ (200 to 1,000 psia).

APEC. Air Products and Chemicals, Inc., has begun research to develop membrane reactors, employing the facilitated transport mechanism to enhance gas separation performance. The transport media, immobilized molten salts, will selectively remove $\mathrm{H}_{2} \mathrm{~S}$ from hot gas streams. Temperatures will range from 538 to $871^{\circ} \mathrm{C}$ $\left(1,000\right.$ to $\left.1,600^{\circ} \mathrm{F}\right)$ and pressures from 1.4 to $4.8 \mathrm{MPa}$ (200 to 700 psia). AP\&C has selected five ceramics for initial compatibility tests with molten alkali salts. They are working to identify the most effective molten salt compositions based on equilibrium measurements and laboratory-determined separation 


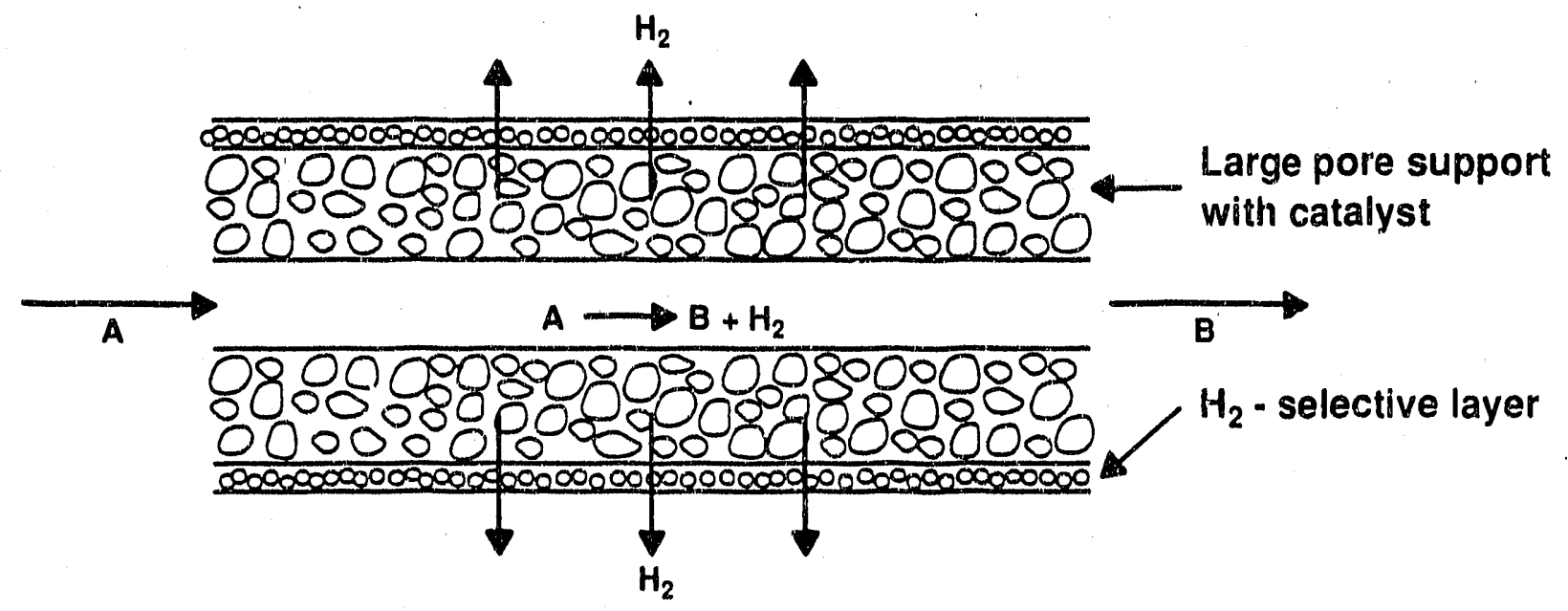

Examples of decomposition reactions:

$$
\begin{gathered}
\mathrm{H}_{2} \stackrel{\text { Cat. }}{\leftrightarrow} \mathrm{S}+\mathrm{H}_{2} \\
2 \mathrm{NH}_{3} \stackrel{\text { Cat. }}{\leftrightarrow} \mathrm{N}_{2}+3 \mathrm{H}_{2}
\end{gathered}
$$

M91000580

\section{Figure 17. Ceramic Catalytic Mambrane}

properties. Coors Ceramics Company will make the ceramic membranes for testing at RTI.

SRT. SRI International is developing a catalyst-impregnated tubular alumina membrane reactor for the IGCC system. These reactors will decompose $\mathrm{H}_{2} \mathrm{~S}$ and $\mathrm{NH}_{3}$ and separate the resulting reaction products. The reactors will operate at temperatures ranging from 538 to $1,093^{\circ} \mathrm{C}\left(1,000\right.$ to $\left.2,000^{\circ} \mathrm{F}\right)$ and pressures from 1.4 to $6.9 \mathrm{MPa}$ (200 to $1,000 \mathrm{psia}$ ).

\section{Surmary}

Gas separation at high temperature is a significant challenge to the membrane science community. However, new materials, instrumentation, and improved understanding by means of computer simulations have allowed membrane technologies to enter tie field of high-temperature separation processes. While the potential. benefits for inorganic membrane gas separation processes are substantial, there are obvious data gaps and uncertainties. The hardware development of seals and sealing materials is critical for demonstrating the overall feasibility of any membrane system. 
Other challenges include improving the understanding of the catalysis, transport and separation mechanisms, compatibility of high-temperature matexials, durability of cerami membranes above $899^{\circ} \mathrm{C}\left(1,650^{\circ} \mathrm{F}\right)$, and performance degradation caused by the presence of coal-derived gas contaminants, notably particulate matter and vapor-phase alkali compounds.

\subsection{Instrumentation}

\section{Al.kal.i Monitoring Rosmarch}

FOAY. During FY 1990, a team of researchers from Ames National Laboratory performed alkali measurements at various advanced coal combustion and gasification facilities. Ames used the METC Fiber Optic Alkali Monitor (FOAM) to measure total sodium and potassium levels in the process gas streams. Alkali measurements for various coals were obtained from the Texaco entrained-bed gasifier, solar DCET combustor, and ANL PFBC. Ames will continue to measure alkali levels at additional advanced combustion/gasification test facilities.

RABSAM. Development of the Regenerable Activated Bauxite Sorbent Alkali Monitor (RABSAM) was continued at ANI during EY 1990. ANI successfully prepared regenerative bauxite sanples capable of capturing vapor-phase alkali compounds. The vaporphase alkali concentration can be calculated from the post-test analysis of the bauxite samples. Future research on the RABSAM concept will include constructing a probe to sample process gas streams.

\section{Smact structiurea}

Researchers at Virginia Polytechnic Institute and state University continued to develop "smart structures" to monitor the properties of ceramic componente. The term "smart structures" refers to fiber optic sensing systems that can detect strain, temperature, and particle cake in ceramic barrier filters. The advantage of smart structures is their ability to provide on-line measurements in harsh operating enviroments. Currently, smart structures axe being evaluated for their ability to predict failures by detecting strains in ceramic cross-flow filters. Testing at the Westinghouse science and Technology Center has confirmed that smart structures can operate at the elevated temperatures and pressures expected during cross-flow filter operation. 


\subsection{Components}

ORNL and their subcontractor, Swanson singineering Associates Corporation, are evaluating tubesheet design and material selection for attachment of ceramic barrier filters (Swindeman, Judkins, and Mallett 1990). The key technical concerns in the desigr of the tubesheet include lack of HTHP operating experience with large-diameter (e.g., $3.05 \mathrm{~m})$ tubesheets, creep fatigue due to thermal cycling, and support of substantial filter weight on a single tubesheet.

Four tubesheet designs were evaluated by Swanson Engineering. The "best" tubesheet design incorporated a bellows to accommodate thermal expansion of the tubesheet and was similar to the tubesheet design used successfully in testing ceramic candle filters at the Grimethorpe RFBC facility. ORNL is evaluating several alloys (e.g., Rolled Alloys RA333 and Haynes 556) for their suitability as HTHP tubesheet materials. Specifically, they are investigating the strength of the weld in the bellows region of the tubesheet since creep fatigue was identified as a life-limiting factor in that region. 


\subsection{ACRONYMS AND ABBREVIATIONS}

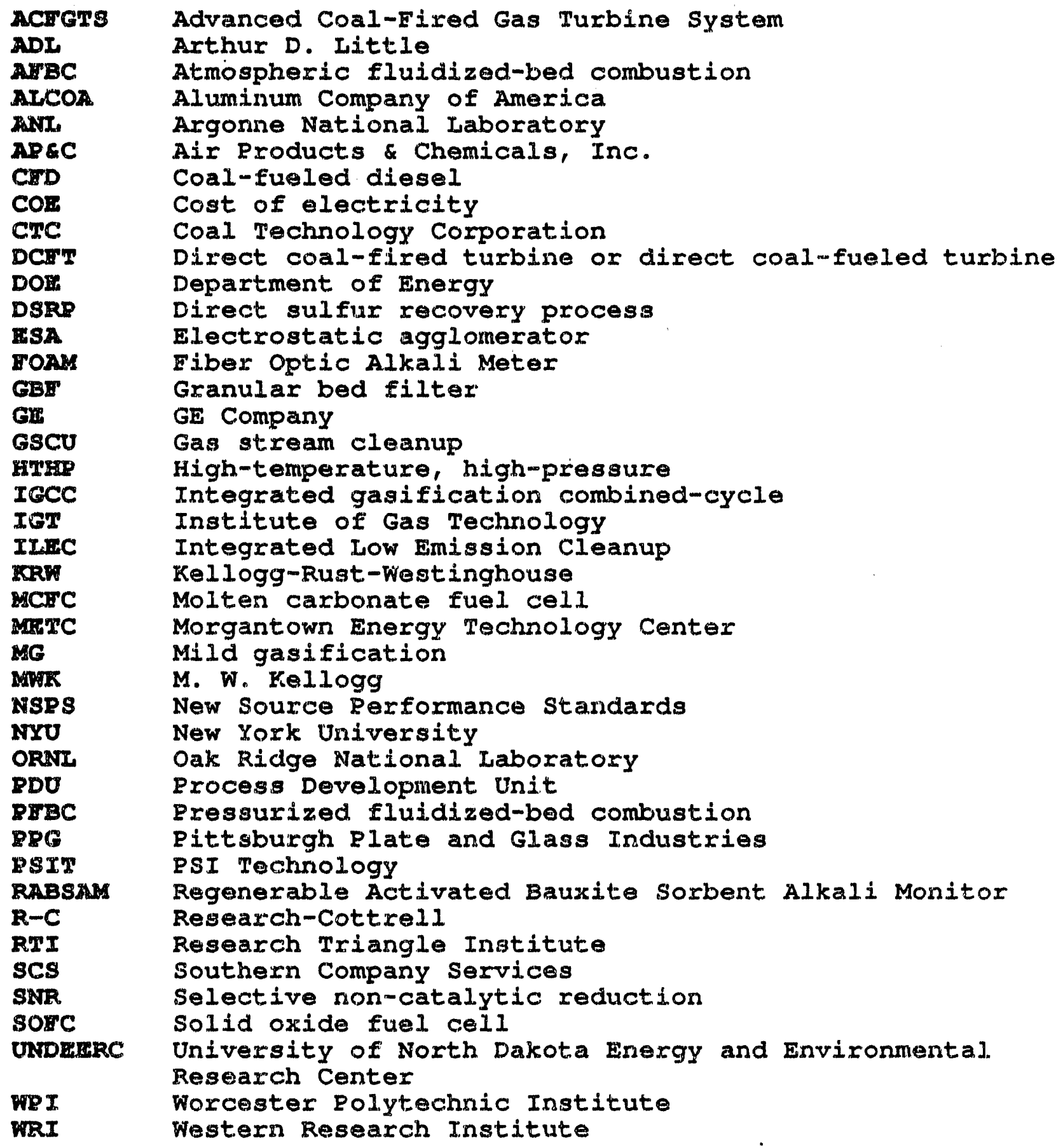

ACEGTS

AICOA

and

CDD

COE

CTC

DSRP

ESA

grOAM

GB:

GSC

EITEP

IGCC

IGT

$M C D C$

$\operatorname{Min} 2$

MG

MATK

ORNI

PDO

PIBC

RPC

RABSAM

$R-C$

RII

SCS

SOrC

WPI

WRI

Advanced Coal-Fired Gas Turbine System

Aluminum Company of America

Argonne National Laboratory

Coal-fueled diesel

Cost of electricity

Department of Energy

GE Company

Gas stream cleanup

High-temperature, high-pressure

Institute of Gas Technology

Integrated Low Emission Cleanup

Kellogg-Rust-Westinghouse

Mild gasification

New York University

Oak Ridge National Laboratory

Process Development Unit

PSI Technology

Research-Cottrel

Research Triangle Institute

southern Company Services

Solid oxide fuel cell

Research Center

Western Research Institute 


\subsection{RTEERRENCES}

Anderson, G.I., F.O. Berry, A.H. Hill, E. Ong, R.M. Laurens, R. Shah, and H.L. Feldkirchner. 1988. Development of a Hot Gas Cleanup system. DOE/MC/22144-2722. NTIS/DE89000937. Springfield, Va.: National Technical Information Sexvice.

Ayala, R.E., E. Gal, S.K. Gangwal, and S.C. Jain. 1990. Enhanced Durability of High-Temperature Desulfurization Sorbents for Moving-Bed Applications. In Preprints of Papers, American Chemical Society, Division of Fuel Chemistry (USA) 35(1):120127 .

Bachovchin, D.M., M.A.Alvin, E.A. DeZubay, and P.R. Murik. 1986. A Study of High Tempexature Removal of Alkali in a Pressurized Gasification System. DOE/MC/20050-2226. NTIS/DE87001035. Springfield, Va.: National Technical Information Service.

Baker, E.G., G.I. Roberts, and I.K. Mudge. 1987. Ammonia Removal in Coal Gasification Processes by Adsoxption on Zeolites. DOE/RI/01830-2520. NTIS/DE88001094. Springfield, Va.: National Technical Information Service.

Bedick, R.C., T.P. Dorchak, N.F. Rekos, and H.A. Webb, eds. 1989. Proceedings of the Sixth Annual Coal-Fueled Heat Engines and Gas Streain Cleanup Systems Contractors Review Meeting. DOE/ ME'TC-89/6101. NTIS/DE89000952. Springfield, Va.: National Technical Information Service.

Bossart, S.J. 1989a. Advanced Earticle Control Technologies for Pressurized Fluidized-Bed Combustion Applications. In Proceedings of the American Rower Conference 51:70-80. Chicago: Illinois Institute of Technology Research Institute.

Bossart, S.J. 1989b. Advanced Particle Control for Coal-Based Power Generation Systems. Paper presented at the Joint ASME/ IEEE Power Generation Conference, October 22-26, 1989, Dallas, Texas. Paper No. 89-JPGC/GT-5.

Bossart, S.J., and C.V. Nakaishi. 1990. Particle Control in Advanced Coal-Based Power Generation Systems. Raper presented at the Eighth Symposium on the Transfer and Utilization of Particulate Control Technology, March 20-23, 1990, San Diego, California. Sponsored by the Electric Power Research Institute and U.S. Environmental. Protection Agency.

Carpenter, I.K., N.T. Holcombe, J.W. Byam, Jr., and M.C. Williams. 1988. Environmental Compatibility of Coal-Fueled Diesel Engines. Papex presented at the ACS Third North American Congress Meeting, June 5-11, 1988, Toronto, Canada. 
Casleton, K.H., V.P. Kothari, and M.C. Williams. 1990. HighTemperature Control Technology for Nitrogen Oxides. Paper presented at 1990 Joint Power Generation Conference, October 21-25, 1990, Boston, Massachusetts. Sponsored by ASME and IEEE.

Chiang, T.K., R.A. Dennis, L.D. Strickland, and C.M. Zeh. 1990. Characterization of Dust Cake Filtration Using Laboratory Measured Quantities. Paper presented at the American Filtration Society Annual Meeting, March 22-25, 1990, Crystal City, Maryland.

Cicero, D.C., and I.A. Jarr. 1989. Application of Ceramic Membranes in Advanced Coal-Based Power Generation Systems. Raper presented at the Fifth Symposium on separation Science and Technology for Energy Applications.

Conkle, H.N., and R.D. Litt. 1988. Nested-Fiber Filter for HighTemperature, Hiah-Pressure Rarticulate Removal. DOE/MC/232512730. NTIS/DE89011700. Springfield, Va.: National Technical Information Service.

Corman, J.C. 1986. System Analysis of Simplified IGCC Plants. DOE/ET/14928-2233. NTIS/DE87002508. Springfield, Va.: National Technical Information Service.

Dellefield, R.J. 1988. High-Temperature Applications of Inorganic Membranes. Paper presented at the AIChE Denver National Meeting, Denver, Colorado.

Dennis, R.A., L.D. Strickland and T.K. Chiang. 1990. Particle Size Effects on High-Temperature Dust Cake Filtration from a Coal-Fired Atmospheric Fluidized-Bed Combustor. Paper presented at the Eighth Symposium on the Transfex and Utilization of Particulate Control Technology, March 20-23, 1990, San Diego, California. Sponsored by the Electric Power Research Institute and U.S. Environmental Protection Agency.

DiBella, C.A.W., R.I. Thomas, I.N. Rubow, and R. Zaharchuk. 1987. Technical and Economical Assessment of Particle Control Technology for Direct Coal Fueled Turbines. DOE/MC/22012-2310. NTIS/DE87001087. Springfield, Va.: National Technical Information Service.

Dorchak, T.P., and S.K. Gangwal. 1990. Direct Sulfur Recovery srocess for Elemental Sulfur Recovery from Gas. In Preprints of Papers, American Chemical Society, Division of Fuel Chemistry (USA) $35(1): 207-216$. 
Dorchak, T.P., S.K. Gangwal, and S.M. Harkins. 1988. SorbentBased Recovery of Sulfur from Regeneration Tail Gases. In Preprints of Papers, American Chemical Society, Division of Fuel Chemistry (USA) 33(1):306-309.

Dorchak T.P., S.K. Gangwal, and W.J. MoMichael. 1990. The Direct Sulfur Recovery Process. Paper presented at the Symposium on Gas Processing, Tail Gas Treatment, 1990 summer National Arnerican Institute of Chemical Engineers Meeting, San Diego, California.

Durner, M.W., and M.J. Mudd. 1990. Tidd PFBC Hot Gas Cleanup Test Facility. In Proceedings of the Seventh Annual Coal-Fueled Heat Engines and Gas Stream Cleanup systems Contractors Review Meeting, 135-140. DOE/METC-90/6110. NTIS/DE90000480. Springfield, Va.: National Technical Information Service.

Gangwal, S.K., S.M. Harkins, and S.C. Jain. 1990. Desulfurization of Hot Coal-Gas in a High-Pressure Fluid-Bed Reactor. In Preprints of Papers, American Chemical Society, Division of Fuel Chemiatry (USA) 35(1):161-169.

Gangwal, S.K., S.M. Harkins, S.C. Jain, and S.J. Bossart. 1989. Bench-Scale Testing of High-Temperature Desulfurization Sorbents. Environmental Progress 8(4):265-269.

Gangwal, S.K., S.M. Harkins, J.M. Stogner, and M.C. Woods. 1988. Multicycle Testing of zinc Eerrite. DOE/MC/23126-2644. NTIS/ DE89000920. Springfield, Va.: National Technical Information Service.

Gangwal, S.K., S.M. Harkins, J.M. Stogner, M.C. Woods, and T.N. Rogers. 1988. Bench-Scale Testing of Novel HighTemperature Desulfurization Sorbents. DOE/MC/23126-2662. NTIS/DE89000935. Springfield, Va.: National Technical Information Service.

Gangwal, S.K., S.M. Harkins, and M.C. Woods. 1988. Disposal of Off-Gases from Hot-Gas Desulfurization Processes. DOE/METC/ 23260-2553. NTIS/DE88001055. Springfield, Va.: National Technical Information Service.

Gangwal, S.K., J.M. Stogrier, S.M. Harkins, and S.J. Bossart. 1989. Testing of Novel Sorbents for $\mathrm{H}_{2} \mathrm{~S}$ Removal E'rom Coal Gas. Environmental Progress $8(1): 26-34$.

Haas, W.J., R. Markuszewski, and D.E. Eckels. 1990. Fiber Optic Alkali Meter Sampling. In Proceedings of Seventh Annual CoalFueled Heat Engines and Gas Stream Contractors Review Meeting, 391-402. DOE/METC-90/6110. NTIS/DE90000480. Springfield, Va.: National Technical Information Service. 
Haldipur, G.B., D.K. Schmidt, and K.J. Smith. 1989. A.50-Month Gasifier Mechanistic Study and Downstream Unit Process Development Program for the Pressurized Ash-Agqlomerating FluidizedBed Gasification System. 2 vols. DOE/MC/21063-2740. NTIS/ DE89011704 and DE89011705. Springfield, Va.: National Technical Information Service.

Jarr, I.A., D.C. Cicero, and R.I. Koch. 1989. High Temperature Ceramic Membranes for Advanced Coal-Based Power Generation Application. Paper presented at the Seventh Annual Membrane Technology/Planning Conference.

Koopman, G.H., and G. Reethof. 1989. Evaluation of Acoustic Agqlomerators for High Pressure, High Temperature Particulate Control. DOE/MC/22012-2916. NTIS/DE91002007. Springfield, Va.: National Technical Information Service.

Krishnan, G. 1988. Study of Ammonia Removal in Coal Gasification Processes. DOE/METC/23087-2667. NTIS/DE89000945. Springfield, Va.: National Technical Information Service.

Lee, S.H.D., D.K. Schmalzer, M.J. Steindler, and W.M. Swift. 1990. Measurements in Alkali Vapors in PFBC Exhaust. In Proceedings of Seventh Annual Coal-Fueled Heat Engines and Gas Stream Contractors Review Meeting, 384-390. DOE/METC-90/6110. NTIS/DE90000480. Springfield, Va.: National Technical Information Service.

Leitch, A.J., and 0.J. Tassicker. 1989. Performance of a Large Ceramic Element Filter Module on a Pressurized Fluidized-Bed Combustor. In Proceedinas: 1988 Seminar on Fluidized-Bed Combustion Technology for Utility Applications, 2-130-1. ERRI GS-6118, Eroject 1179 .

Lippert, T.E., M.A. Alvin, D.M. Bachovchin, G.B. Haldipur, R.A. Newby, and E.E. Smeltzer. 1990. Cross Flow Filter Development for Advanced Eossil Power Generation. Paper presented at the 1990 ASME Joint Power Generation Conference, October 21-25, 1990, Boston, Massachusetts.

Lippert, T.E., D.M. Bachovchin, E.E. Smeltzer, J.H. Meyer, and E.J. Vidt. 1989. Performance Evaluation of a Ceramic Cross F'low Filter on a Bench-Scale Coal Gasifier. 2 vols. DOE/MC/213382749. NTIS/DE90000404 and DE90000405. Springfield, Va.: Nationa. Technical Information Service.

Lippert, T.E., G.E. Haldipur, E.E. Smeltzer, and J.H. Meyer. 1989. Rerformance Evaluation of a Cross-Flow Filter on a Subpilot-scale Pressurized Fluid Bed Coal Combustor. DOE/MC/ 22136-2817. NTIS/DE90000477. Springfield, Va.: National Technical Information Service. In press. 
Litt, R.D., and H.N. Conkle. 1990. Nested-Eiber Eilter for Particulate Control. Paper presented at the ERA/ERRI 8th Symposium on Particulate Control. Technology, San Diego, California.

Magee, T.P., H.R. Kunz, M. Krasij, and H.A. Cote. 1987. The Effects of Halides on the Perfommance of Coal Gas-Fueled Molten Carbonate E'uel Ce11s. DOE/MC/23136-2558. NTIS/DE88001058. Springfield, Va.: National Technical Information Service.

McMichael, W.J., S.K. Gangwal, and S.J. Bossart. 1990. Hot Gas Cleanup in Gasification-Bared Power Generation Systems. Paper presented at the 1990 ASME Joint Power Generation Conference, October 21-25, 1990, Boston, Massachusetts.

Morgantown Energy Technology Center. 1986. Hot Gas Cleanup for Electric Power Generating Systems. DOE/METC-86/6038. NTIS/ DE86006607. Springfield, Va.: National Technical Information Service.

Newby, R.A., E.A. Dezubay, and R.M. Chamberlain. 1987. Laboratory Evaluation of High-Temperature Sulfur Removal sorbents for Direct Coal-Fired Turbines. DOE/MC/22087-2543. NTIS/DE88001041. Springfield, Va.: National Technical Information Service.

Parsons, E.L., Jr., H.A. Webb, and C.M. Zeh. 1990. Assessment of Hot Gas Cleanup Technologies in Coal-Eired Gas Turbines. American Society of Mechanical Engineers Papers.

Pigeaud, A., and J. Klinger. 1987. Study of the Effects of Soot, Particulate, and other Contaminants on Molten Carbonate Fuel Cel1s Eueled by Coal Gas. DOE/MC/21154-2559. NIIS/DE88001059. Springfield, Va.: National Technical Information Service.

Reethof, G。, G. Koopman, and T.P. Dorchak. 1989. Acoustic Agglomeration for Particulate Control at High-Temperature and High Pressure - Some Recent Results. Paper presented at ASME Winter Meeting - Session on High Intensity Acoustic Applications in Coal Fired Power Plants, December 10-15, 1989, San Francisco, California. Sponsored by American Society of Mechanical Engineers.

Remick, R.J., J.R. Jewulski, and S.H. Lu. 1987. Contaminant Resistant Molten Carbonate Fuel Cel1. DOE/MC/23023-2549. NTIS/ DE88001047. Springfield, Va.: National Technical. Information Service.

Robin, A.M., J.C. Wu, and J.S. Kassman. 1990. Integration and Testing of Hot Desulfurization and the Texaco Coal Gasification Process for Power Generation. Paper presented at the American Chemical Society, 199th National Meeting, April 22-27, 1990, Boston, Massachusetts. 
Smeltzer, E.E., T.E. Lippert, and D.M. Bachovchin. 1990. Long Term Durability Testing of Ceramic Cross Flow Filter. In vol. 1 of Proceedings of the Tenth Annual Gasification and Gas Stream Cleanup Contractors Review Meeting, 130-135. DOE/METC-90/6115. NTIS/DE90009689. Springfield, Va.: National Technical Information service.

Smith, D.P. 1988. Design Studies for Gasification/Hot Gas Desulfurization system Operation in a Load Eollowing Mode. DOE/ MC22247-2859. NTIS/DE90009674. Springfield, Va.: National Technical Information Service.

Swindeman, R.W., R.R. Judkins, and R.H. Mallett. 1990. Identification of Materials for Hot-Gas Filter Tubesheets. In Proceedings of Seventh Annual Coal-Fueled Heat Engines and Gas Stream Contractors Review Meeting, 179-184. DOE/METC-90/6110. NTIS/DE90000480. Springfield, Va.: National Technical Information Service.

Unnasch, S. 1987. Ammonia Removal in Coal Gasification Processes Using Integrated systems Approach. DOE/MC/23275-2589. NTIS/ DE88001096. Springfield, Va。: National Technical Information Service.

Webb, H.A., N.F. Rekos, V.P. Kothari, and R.C. Bedick, eds. 1990. Proceedings of the Seventh Annual Coal-Eueled Heat Engines and Gas Stream Cleanup Systems Contractors Review Meeting. DOE/ METC-90/6110. NTIS/DE90000480. Springfield, Va.: National Technical Information Service.

Williams, M.C., and R.C. Bedick. 1988. Gas Stream Cleanup Technology Status Report. DOE/METC-89/0263. NTIS/DE89000925. Springfield, Va.: National Technical Information Service.

Williarns, M.C., and D.C. Cicero. 1988. The Department of Energy's Program for Characterizing PFBC Exhausts with the METC Fiberoptic Alkali Monitor. American Society of Mechanical Engineers Papers.

Williams, M.C., and D.C. Cicero. 1989. Alkali Behavior in Advanced Coal Fueled Systems. Paper presented at the Joint ASME/IEEE Power Generation Conference, October 22-26, 1989, Dallas, Texas. Paper No. 89-JPGC/EC-3.

Williams, M.C., and V.P. Kothari. 1989. High-Temperature Nitrogen Control Technology for Coal Conversion systems. American Society of Mechanical Engineers Papers. 
Wilson, K.B., and J.C. Haas. 1990. Performance Analysis of a Screenless (Counter-Current) Granular Bed Filter on a SubpilotSCale REBC. 2 vols. DOE/MC/21335-2823. NTIS/DE90000486\& DE90000487. Springfield, Va.: National Technical Information Sexvice.

Woodland, I.J. 1988. Investigation of Processes to Treat Zinc Eerrite Regeneration Offaases in High Temperature Desulfurization of Coal Gases. DOE/MC/23086-2798. NTIS/DE90000460. Springfield, Va.: National Technical Information Service.

Zakkay, V., K.M. Sellakumar, R.J. Dellefield, and S.J. Bossart. 1988. Advanced Rarticle Control Research at the New York University Coal-Fired Pressurized Fluidized-Bed Combustion Eacility. In Rroceedings: 1988 Seminar on Fluidized-Bed Combustion Technology for Ut lilty Applications. ERRI-GS-6118. CONE-880550. NTIS/DE89008769. Springfield, Va.: National Technical Information Service. 


\subsection{BIBLIOGRAPEY}

This bibliography lists recent reports containing information on many gas stream cleanup projects.

Baird, M.J., I.A. Jarx, J.R. Loganbach, and M.C. Williams, eds. 1989. Eroceedings of the Separations lechnology Workshop for Coal Gasification. DOE/METC-89/6100. NTIS/DE89000905. Springfield, Va.: National Technical Information Service.

Bedick, R.C., and V.R. Kothari, eds. 1988. Gas Stream Cleanue Papers from DOE/METC Sponsored Contractors Review Meetings in 1988. DOE/METC-89/6099. NTIS/DE89000901. Springfield, Va.: National Technical Information Service.

Byam, J.W., Jr., and K.E. Markel, Jr., eds. 1987. Proceedings of the Annual Heat Enaines and Gas stream Cleanup systems Contractorg Review Meeting. DOE/METC-87/6077. NTIS/DE87001072. Springfield, Va.: National Technical Information Service.

Dellefield, R.J., and H.A. Webb, eds. 1988. proceedings of the Annual Coal-Fueled Peat Engines and Gas stream Cleanup Systems Contractors Review Meeting. DOE/METC-88/6094. NTIS/DE88001088. Springfield, Va.: National Technical Information Service.

Ghate, M.R., K.E. Markel, Jr., L.A. Jarr, and S.J. Bossart, eds. 1987. Eroceedings of the Seventh Annual Gasification and Gas Stream Cleanup Systems Contractors Review Meeting. 2 vols. DOE/METC-87/6079. NTIS/DE87006495 and DE87006496. Springfield, Va.: National Technical Information Service.

Huber, W.J., ed. 1990. Proceedings of the Second Annual Euel Celis Contractorg Roview Meeting. DOE/METC-90/6112. NTIS/ DE90000490. Springfield, Va.: National Technical Information Service.

Johnson, R.A., and T.P. Dorchak, eds. 1989. Proceedings of the Ninth Annual Gasification and Gas stream Cleanup Systems Contractors Review Meeting. 2 vols. DOE/MirTC-89/6107. NTIS/ DE89011706 and DE89011707. Springfield, Va.: National Technical Information Service.

Kothari, V.P., and J.I. Beeson, eds. 1990. Proceedings of the Tenth Annual Gasification and Gas stream Cleanup Systeras Contractors Review Meeting. 2 vols. DOE/METC-90/6115. NTIS/ DE90009689 and DE90009690. Springfield, Va.: National Tachnical Information service. 
Kothari, V.P., and J.R. Loganbach, eds. 1988. Proceedings of the Eighth Annual Gasification and Gas Stream Cleanup Systems Contractors Review Meeting. 2 vols. DOE/METC-88/6092. NTIS/ DE88010253 and DE88010254. Springfield, Va.: National Technical Information Service.

Markel, K.E., Jr., ed. 1987. Gas Stream Cleanup Papers from DOE/METC - Sponsored Contractors Review Meetings in 1987. DOE/METC-87/6082. NTIS/DE87006516. Springfield, Va.: National Technical Information service. 

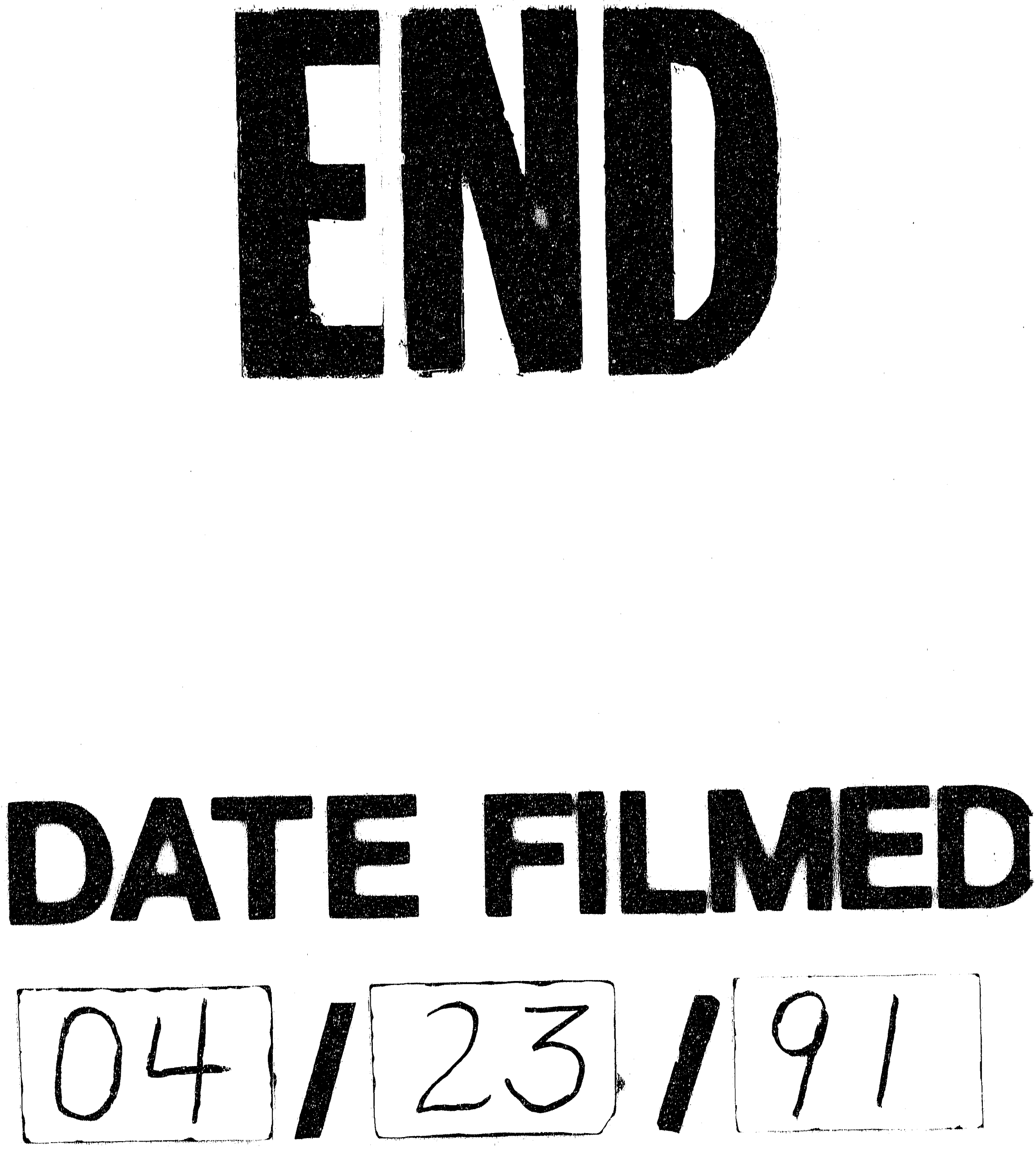
承

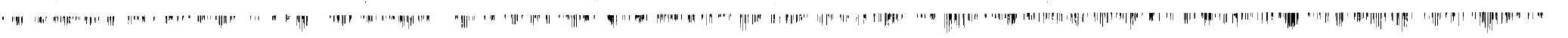

